\title{
STANY NADZWYCZAJNE W PORZĄDKU KONSTYTUCYJNYM UKRAINY - STAN WOJENNY 2018 ROKU
}

$\mathrm{W}$ artykule autor analizuje normy prawne dotyczące stanów nadzwyczajnych w porządku konstytucyjnym Ukrainy, które są ujęte w specjalny obszar regulacji. Badanie problemów z nimi związanych odbywa się na podstawie ukraińskich i zagranicznych rozwiązań konstytucyjnych i ustawowych. Ukraiński ustrojodawca określił w konstytucji podstawowe zasady systemu prawnego dotyczące funkcjonowania państwa w sytuacjach nadzwyczajnych. W pracy zostały omówione zagadnienia dotyczące: stanu wyjątkowego, stanu wojny, stanu klęski żywiołowej i stanu wojennego. Niestety rozwój technik prowadzenia konfliktów zbrojnych i oficjalnie niewypowiedziana wojna Federacji Rosyjskiej i jej najemników przeciwko Ukrainie wymuszają liczne zmiany prawa. W zaistniałej sytuacji władze rosyjskie dopuszczają się na terenie Ukrainy łamania wielu podstawowych praw człowieka, czemu musi przeciwdziałać państwo ukraińskie. Na szczególną uwagę zasługuje analiza norm prawnych i działań organów państwowych podczas stanu wojennego, wprowadzonego w grudniu 2018 r. w 10 regionach (województwach) Ukrainy, a także przesłanek jego wprowadzenia. Omawiane problemy wskazują na kryzys dyplomacji. Współczesne przejawy niszczenia międzynarodowego zaufania oddziałują także na bezpieczeństwo Polski i całej Europy Środkowo-Wschodniej.

Słowa kluczowe: stany nadzwyczajne, stan wyjątkowy, stan wojny, obszary nadzwyczajnej sytuacji ekologicznej, stan wojenny, porządek konstytucyjny Ukrainy, cyberwojna, cyberprzestrzeń, cyberterroryzm

\section{EXTRAORDINARY STATES IN THE CONSTITUTIONAL ORDER OF UKRAINE - MARTIAL LAW IN 2018}

In this publication, the author analyzes legal norms concerning extraordinary states in the Constitution of Ukraine. The problems are examined based on Ukrainian and foreign constitutional and statutory solutions. In the Constitution, the Ukrainian constitutional legislator specified the fundamental principles of the legal system related to the functioning of the state in extraordinary situations. In the paper, the following are discussed: state of emergency, state of war, state of natural disaster and martial law. Unfortunately, the development of armed conflict techniques and the officially undeclared war of the Russian Federation and its mercenaries against Ukraine enforce multiple law amendments. Currently, Russian authorities violate multiple human rights in the territory of Ukraine. Particularly noteworthy is the analysis of legal norms and a description of martial law, which was introduced in 2018 in 10 oblasts (provinces) of Ukraine as well as the reasons for its introduction. The discussed problems are a manifestation of the diplomacy crisis. The current manifestations of the destruction of international trust also affect the security of Poland and all of the Central-Eastern Europe.

Key words: extraordinary states, state of emergency, state of war, areas of extraordinary ecological situation, martial law, constitutional order of Ukraine, cyberwar, cyberspace, cyberterrorism

* Dr Andrzej Stec, Uniwersytet Zielonogórski, Wydział Prawa i Administracji, Katedra Organizacji Administracji Publicznej, stec75@wp.pl, https://orcid.org/0000-0002-3014-2400 


\section{UWAGI WSTĘPNE}

tany nadzwyczajne są szczególnym obszarem regulacji ustrojowych związa$\checkmark$ nych z wyjątkowym zagrożeniem dla funkcjonowania państwa oraz życia i zdrowia wielu osób. Współcześnie do zagrożeń bezpieczeństwa państw zalicza się m.in. terroryzm, wojnę hybrydową, przestępczość zorganizowaną. Ryzyko wystąpienia tych zjawisk istnieje nie tylko w świecie rzeczywistym, ale także i w wirtualnym. W tej drugiej sferze należy dostrzec nowe, ale też znane dotychczas, lecz ewoluujące patologie, takie jak cyberprzestępczość, cyberterroryzm, a nawet cyberwojnę, które pojawiły się wskutek rozwoju Internetu oraz nowych technik teleinformatycznych. Każde państwo może spotkać się z tego typu niebezpieczeństwami zakłócającymi jego funkcjonowanie zwłaszcza w sferze infrastruktury krytycznej. W zależności od rodzaju i zakresu zagrożeń państwo będzie zmuszone przedsięwziąć szczególne działania swoich organów, wykraczające ponad te podejmowane w ramach zwykłych środków konstytucyjnych. Dotyczy to m.in. szczególnych sposobów administrowania polegających na przyjęciu specjalnych uprawnień przez głowę państwa, rząd oraz podległe im organy administracji ogólnej, samorządowej, oraz organy wojskowe i policyjne.

Za istotny problemem badawczy należałoby uznać zasadność użycia wyjątkowych środków prawnych dla ratowania dobra wspólnego — niepodległości Ukrainy. Wybór tematu jest związany z bezpieczeństwem sąsiedniego państwa, które oddziałuje także na bezpieczeństwo Polski i Europy Środkowo-Wschodniej. Racjonalnym działaniem jest skorzystanie w pracy z metody prawnodogmatycznej, opartej na analizie przepisów prawnych obowiązujących na Ukrainie, oraz metody prawnoporównawczej umożliwiającej ulepszenie funkcjonowania instytucji opierających się na już sprawdzonych i funkcjonujących organach w innych państwach. W niewielkim zakresie należałoby skorzystać z metody prawnohistorycznej, choć połączenie metod historycznych i metod badania prawa pozwala na dogłębne i właściwe pokazanie treści norm prawnych, uwzględniających dynamikę zmian społecznych oraz politycznych.

Wydarzenia „,rewolucji godności” (zwanej także „,euromajdanem”) na Ukrainie ${ }^{1}$ oraz stworzenie ruchu społecznego mającego na celu obronę prawa obywateli do przyrodzonej każdemu człowiekowi godności i możliwości wyboru kierunku rozwoju państwa zostały brutalne rozpędzone 30 listopada 2013 r. przez jednostki specjalne milicji (Berkut)². Zamordowanie ok. 100 osób z tzw. niebiańskiej sotni w Kijowie oraz łącznie ok. 780 na terenie całego kraju wywołało falę oburzenia i doprowadziło do umasowienia ruchu w całym państwie, jak również przyczyniło się pośrednio do rozpoczęcia niewypowiedzianej wojny przez Federację Rosyjską [dalej: FR] przeciwko Ukrainie, która pochłonęła już przeszło 15 tys. ofiar oraz zmusiła ok. 3,5 miliona obywateli do uchodźctwa (wewnętrznego, zewnętrznego, zarobkowego) i trwa ona do dziśs.

1 Vide szerzej М. Вітер, Літопис Революції Гідності, Львів 2017, s. 8-208.

${ }^{2}$ Confer G. Kowalski, Przewrót konstytucyjny na Ukrainie w 2014 r. Analiza konstytucyjno-prawna, „Przegląd Sejmowy” 2018, nr 1, s. 31-55. 


\section{STANY NADZWYCZAJNE: STAN WOJNY I STAN NADZWYCZAJNEJ SYTUACJI EKOLOGICZNEJ NA UKRAINIE}

Termin „stany nadzwyczajne” obejmuje instytucje prawa wewnętrznego, polegające na odstąpieniu od konstytucyjnego systemu sprawowania władzy w sytuacji zaistnienia szczególnego zagrożenia, którego przezwyciężenie wymaga skorzystania z wyjątkowych środków. „Celem każdego stanu nadzwyczajnego jest przeciwstawienie się zagrożeniom i ratowanie dobra wspólnego"3. Przesłankami wprowadzenia stanów nadzwyczajnych jest powstanie w państwie szczególnych (realnych) zagrożeń dla życia i zdrowia obywateli lub bezpieczeństwa państwa, których usunięcie innymi sposobami nie jest możliwe. Do takich zagrożeń możemy zaliczyć klęski żywiołowe, katastrofy mogące powodować straty materialne i ludzkie w dużych rozmiarach, masowe łamanie prawa, wewnętrzne konflikty zbrojne, próby przejęcia siłą władzy państwowej oraz zmiany porządku konstytucyjnego ${ }^{4}$. W związku z tym, że pojęcie „porządek konstytucyjny” nie doczekało się ani w polskiej, ani w ukraińskiej nauce prawa konstytucyjnego ściśle określonego znaczenia, należy zastosować je do oznaczenia szerszego zakresu zjawisk niż system konstytucyjny czy prawo konstytucyjne. Znaczenie stanów nadzwyczajnych w porządku konstytucyjnym Ukrainy jest zagadnieniem złożonym, bowiem dotyka zasadniczych sporów o charakterze teoretycznym, kluczowych dla mechanizmu państwowego. „Problem ochrony wartości konstytucyjnych na Ukrainie w sytuacjach nadzwyczajnych wydaje się zbyt zbiurokratyzowany w systemie zarządzania narodowym bezpieczeństwem i obroną" Porządek konstytucyjny należy rozważać jako zjawisko społeczne, na które składają się powiązane ze sobą obszary działalności różnych podmiotów. Przedstawiony w artykule obraz stanów nadzwyczajnych odbiega od ujęcia statycznego, w którym byłby określany jedynie przez pryzmat zespołu (systemu) norm prawnych. Na porządek konstytucyjny Ukrainy składa się działalność takich uczestników (podmiotów) życia społecznego, jak: elektorat (zaangażowany i niezaangażowany), sądownictwo, doktryna (nauka) i polityka (ludzie i instytucje) oraz treść przepisów prawnych i norm wyprowadzonych z tych przepisów przez doktrynę i orzecznictwo. Przy czym każdego z uczestników życia społecznego należy traktować jako względnie niezależnego od pozostałych, obdarowanego autonomią działania, której zakres jednocześnie definiuje tożsamość. Działania żadnego z nich nie determinują do końca działań pozostałych, a w niektórych przypadkach mogą ograniczać zakres możliwości działania innych uczestników. Zarysowany obraz porządku konstytucyjnego nie jest jednak pełny, bowiem nie obejmuje tak istotnych czynników, jak działalność administracji rządowej oraz instytucjonalnych czynników, których nie zalicza się do obszaru tradycyjnej polityki, a wyrażających czyjeś interesy i przekonania (np. związków zawodowych, mniejszości narodowych i religijnych) ${ }^{6}$.

${ }^{3}$ B. Banaszak, Konstytucja Rzeczypospolitej Polskiej. Komentarz, Warszawa 2012, s. 1086.

${ }^{4}$ П. Шляхтун, Конституиійне право: словник термінів, Київ 2005, s. 268.

${ }^{5}$ М. Савчин, Сучасні тенденції конституціоналізму у контексті глобалізації та правового плюралізму, Ужгород 2018, s. 184.

${ }^{6}$ Vide М. Савчин, Конституціоналізм і природа конститучії: теорія і практика реалізації, Дисертачія на здобуття наукового ступеня доктора юридичних наук Ужгород, 2013, s. 148-236. 
Takie ujęcie porządku konstytucyjnego wskazuje na złożoność procesów w nim zachodzących, na które składa się działalność nie tylko polityków, lecz także innych uczestników, których wystąpienia nie są ze sobą skoordynowane. Natomiast ich działania są wzajemnie od siebie zależne, co powoduje, że impuls wychodzący od jednego z nich podlega przekształceniu i reinterpretacji u pozostałych. Niesie to ze sobą istotne konsekwencje, gdyż działalność któregokolwiek z wymienionych uczestników nie przesądza o kształcie porządku konstytucyjnego Ukrainy. Jest raczej efektem działań i zaniechań wszystkich podmiotów. Wprowadzenie do tekstu konstytucji stanów nadzwyczajnych wynikało z zapotrzebowania, tradycji postradzieckiej oraz wyzwań w niestabilnych czasach na Ukrainie. W konstytucjach państw demokracji ludowej lub demokracji socjalistycznej, czyli państw zależnych od Związku Socjalistycznych Republik Radzieckich (tzw. bloku wschodniego) korzystano z różnych terminów na określenie stanów nadzwyczajnych: stan wojny ${ }^{7}$, stan obrony $^{8}$, stan wojenny ${ }^{9}$, stan wyjątkowy ${ }^{10}$ a także stan dużego zagrożenia bezpieczeństwa państwa ${ }^{11}$. Kopią konstytucji ZSRR z 7 października 1977 r. na Ukrainie była Konstytucja Ukraińskiej Socjalistycznej Republiki Radzieckiej z 20 kwietnia 1978 r., w której po nowelizacji z 14 lutego 1992 r. wprowadzono terminy stanu wojny i stanu wojennego (art. 114-5 pkt 12) oraz ogłoszenia określonych terenów obszarami nadzwyczajnej sytuacji ekologicznej (art. 114-5 pkt 13) ${ }^{12}$. Konstytucja ta obowiązywała na Ukrainie do 1996 r. Należy zaznaczyć, że Ukraina z pewną przerwą po odzyskaniu niepodległości wprowadziła wspomniane wyżej instytucje ${ }^{13}$, a określenie nazwy trzeciego stanu nadzwyczajnego, tj. nadzwyczajnej sytuacji ekologicznej było związane z katastrofą elektrowni atomowej w Czarnobylu 26 kwietnia 1986 r. ${ }^{14}$

Kryzys radzieckiego systemu politycznego związany z próbą powstrzymania rozpadu systemu komunistycznego (tzw. pucz moskiewski lub pucz Janajewa) przyśpieszył powołanie na Ukrainie instytucji stanu wojennego. W nocy z 18 na 19 sierpnia 1991 r. doszło w Moskwie do zamachu stanu. Delegacja samozwańczego (ośmio-

7 Vide konstytucje: Czechosłowackiej Republik Socjalistycznej — art. 36 pkt 2, art. 61 pkt 1; Polskiej Rzeczypospolitej Ludowej — art. 33; Węgier — §19; ZSRR — art. 121 pkt 17.

${ }^{8}$ Konstytucja Niemieckiej Republiki Demokratycznej — art. 7 i 8.

${ }^{9}$ PRL art. 33, ZSRR art. 121 pkt 15.

${ }^{10}$ Bułgaria - art. 94 pkt 8.

11 Węgry $\S 31$.

12 Конституція (Основний Закон) України, <https://zakon.rada.gov.ua/laws/show/888-09>, dostęp 29 I 2019.

${ }^{13}$ Zarówno przyjęta przez Radę Najwyższą USRR 16 lipca 1990 r. Deklaracja o suwerenności państwowej Ukrainy jak również Akt Niepodległości Ukrainy z 24 sierpnia 1991 r. nie przewidywały instytucji stanu wojennego. Ten zabieg ówcześnie tłumaczono przyjęciem doktryny neutralnego statusu niezależnej Ukrainy we wspomnianej deklaracji oraz w omawianej koncepcji nowej konstytucji Ukrainy w czerwcu $1991 \mathrm{r}$.

${ }^{14}$ Była to największa katastrofa $\mathrm{w}$ energetyce jądrowej i jedna $\mathrm{z}$ największych katastrof przemysłowych XX w. W wyniku awarii skażeniu promieniotwórczemu uległ obszar od 125 tys. do 146 tys. km² terenu na pograniczu obecnej Białorusi, Ukrainy i Federacji Rosyjskiej [dalej: FR], a wyemitowana z uszkodzonego reaktora chmura radioaktywna rozprzestrzeniła się po całej Europie. W efekcie skażenia ewakuowano i przesiedlono ponad 300 tys. osób z okolic Czarnobyla na sowieckiej wówczas Ukrainie. 
osobowego) tzw. Państwowego Komitetu Stanu, na czele z wiceprezydentem ZSRR Giennadijem Janajewem ogłosiła na niemal całym terytorium ZSRR stan wyjątkowy, który miał obowiązywać przez pół roku. Wprowadzono ponownie cenzurę, zakaz demonstracji i strajków oraz godzinę milicyjną po 23, aresztowano Prezydenta ZSRR Michaiła Gorbaczowa. W dniu 21 sierpnia 1991 r., nie uzyskawszy poparcia społeczeństwa, pucz upadł.

Wykorzystując zamieszanie wywołane puczem, Rada Najwyższa Ukraińskiej Socjalistycznej Republiki Radzieckiej 24 sierpnia 1991 r. uchwaliła Akt Niepodległości Ukrainy, zdelegalizowała Komunistyczną Partię Ukrainy oraz rozpoczęła prace usamodzielniające Ukrainę jako niezależne państwo (w tym dotyczące instytucji stanu wojennego, który miałby zabezpieczyć niezależność i integralność w przypadku agresji). We wszystkich omawianych projektach kluczowa rola przy wprowadzaniu stanów nadzwyczajnych przypadała głowie państwa. Ostateczny kształt instytucji stanu wojennego na Ukrainie znalazł odzwierciedlenie w art. 106 konstytucji przyjętej 28 czerwca 1996 r. ${ }^{15}$ i jej nowelizacjach w 2004 r., 2010 r. oraz 2014 r. Kolejne nowelizacje ustawy zasadniczej praktycznie nie zmieniały norm dotyczących stanu wojennego ani nie były zastosowane w praktyce i można je określić jako symboliczne $\mathrm{z}$ jednym groźnym incydentem ${ }^{16} \mathrm{w} 2003 \mathrm{r}$.

Niezależnie od funkcji i zadań prezydenta jako najwyższego głównodowodzącego sił zbrojnych Ukrainy należy pamiętać, że przysługują mu istotne uprawnienia odnoszące się do tzw. stanów nadzwyczajnych ${ }^{17}$, gdyż każde państwo, niezależnie od czasu i miejsca, ustroju politycznego, jest narażone na różnego rodzaju niebezpieczeństwa i kryzysy ${ }^{18}$. W celu usunięcia tych zagrożeń musi posługiwać się środkami na co dzień trudnymi do zaakceptowania w demokratycznym społeczeństwie, które

${ }_{15}$ Конституція України, Прийнята на п’ятій сесії Верховної Ради України 28 червня 1996 року, Харків 1996.

${ }^{16}$ Konflikt o Tuzłę - spór (incydent) polityczny między Ukrainą a FR o przynależność terytorialną ukraińskiej wyspy Tuzła leżącej w Cieśninie Kerczeńskiej, trwający od września do listopada 2003 r., w którym stanowczość prezydenta Ukrainy L. Kuczmy i konsolidacja wojsk ukraińskich przy wyspie oraz groźba ich użycia odwiodły wojska rosyjskie od jej zajęcia. Incydent zakończył się uznaniem w lipcu 2005 r. przez FR, że wyspa Tuzła i okoliczne wody należą do Ukrainy.

${ }^{17}$ Idea wprowadzania nadzwyczajnych uregulowań na czas zagrożenia państwa wywodzi się z okresu starożytnej republiki rzymskiej. Pierwowzorem nowożytnej regulacji stanów nadzwyczajnych była instytucja dyktatora, powoływana w sytuacji zagrożenia państwa. Był to „nadzwyczajny urzędnik mianowany przez jednego z konsulów w momentach, gdy państwu groziło niebezpieczeństwo z zewnątrz lub wewnętrzny kryzys. Dyktatora wyznaczano najwyżej na 6 miesięcy, on sam zaś mianował swego zastępcę, którym był magister equitum, miał władzę nieograniczoną, nie podlegał intercesji trybunów ludowych, a od jego wyroków nie było odwołania do zgromadzeń ludowych. Po wygaśnięciu pełnomocnictw dyktator nie był obowiązany do składania sprawozdań. Dyktatury Sulli i Cezara były dożywotnie i miały inny charakter". Prawo rzymskie. Stownik encyklopedyczny, red. W. Wołodkiewicz, W. Rozwadowski, J. Kamiński, Warszawa 1986, s. 49. Vide N. Maszkin, Historia starożytnego Rzymu, Warszawa 1953, s. 168; M. Jaczynowska, Historia starożytnego Rzymu, Warszawa 1978, s. 81.

${ }^{18}$ Stąd uważa się, że problematyka stanów nadzwyczajnych ma charakter globalny. Vide J. Akande, States of Emergency, [w:] The New Constitutional Law. International Association of Constitutional Law. Second World Congres, Paris 1987, s. 200. 
mogą być nawet sprzeczne z ideami kształtującymi fundament państwa. Organem wzmacniającym pozycję głowy państwa w tej materii jest Rada Bezpieczeństwa Narodowego i Obrony Ukrainy ${ }^{19}$.

Narzędziami prawnymi, zapewniającymi usunięcie szczególnego zagrożenia dla państwa i jego obywateli, są stany nadzwyczajne. Termin „stan nadzwyczajny” w państwie demokratycznym oznacza reżim prawny wprowadzony w razie wystąpienia szczególnego zagrożenia, którego usunięcie jest możliwe tylko za pomocą środków o wyjątkowym charakterze. Reżim ten cechuje się przede wszystkim ograniczeniem (zawieszeniem) określonych praw i wolności jednostki. Może również wystąpić przesunięcie kompetencji między organami władzy publicznej lub nadanie im szczególnych uprawnień służących usunięciu powstałego zagrożenia ${ }^{20}$. Większość demokratycznych państw w sytuacji szczególnego zagrożenia decyduje się na użycie środków godzących w elementarne zasady, którymi kierują się w normalnej sytuacji. Jak stwierdził Krzysztof Wójtowicz, ,[...] demokracja nie może bowiem być bezbronna tak wobec zamachów na swe instytucje, jak i wobec innych sytuacji obiektywnie grożących załamaniem porządku społecznego. Nie do przyjęcia byłaby teza, iż skuteczność w takim przypadku jest przywilejem państwa totalitarnego"21.

Intersujące poglądy w zakresie konstrukcji i systematyki omawianej materii ma Michał Brzeziński, rozpatruje je w szerszej perspektywie niż pojęcie z zakresu prawa konstytucyjnego ${ }^{22}$. Łączy on wiedzę teoretyczną ze sprawdzonymi regulacjami prawnymi ${ }^{23}$.

19 Jest powoływana przez prezydenta, który jej przewodniczy, co pomaga mu spełniać wyznaczoną przez konstytucję rolę gwaranta bezpieczeństwa narodowego. Biorąc pod uwagę, że spośród czterech przedstawicieli rządu dwóch należy do tzw. resortów prezydenckich, głowa państwa może skutecznie kontrolować działalność struktury, w której decyzje podejmowane są większością 2/3 głosów. A. Ławniczak, Monarchiczne i republikańskie glowy państwa w Europie, Wrocław 2011, s. 269.

${ }^{20}$ K. Prokop, Stany nadzwyczajne w Konstytucji Rzeczypospolitej Polskiej z dnia 2 kwietnia 1997 r., Białystok 2005, s. 9.

${ }^{21}$ K. Wójtowicz, Stany nadzwyczajne (analiza prawno-porównawcza z uwzględnieniem projektu Konstytucji RP), Archiwum Sejmu, Komisja Konstytucyjna Zgromadzenia Narodowego, „Ekspertyzy” 1995/96, nr 68, s. 1.

${ }_{22}$ Zdaniem M. Brzezińskiego, „Relacje między stanem nadzwyczajnym a stanami nadzwyczajnymi jest następująca. Stan nadzwyczajny (zawsze w liczbie pojedynczej) to konstrukcja, w której niczym w soczewce koncentrują się wszystkie problemy stanów nadzwyczajnych. To model, dzięki któremu problemy te można analizować w oderwaniu od doraźnych uwarunkowań polityczno-prawnych, jakie towarzyszą stanom nadzwyczajnym, a następnie na ich podstawie formułować ogólne i usystematyzowane obserwacje. Z kolei stany nadzwyczajne zawsze w liczbie mnogiej, oznaczają konkretne regulacje prawne współtworzące system prawa, które posiadając cechy stanu nadzwyczajnego, posiadają w efekcie przymiot nadzwyczajności. Przykładowo będą to: stan wojenny, wyjątkowy czy klęski żywiołowej. Wiedza płynąca z zajmowania się stanami nadzwyczajnymi i analizy ich poszczególnych regulacji z reguły wzbogaca wiedzę dotyczącą stanu nadzwyczajnego. Wnioski wynikające z rozpatrywania stanu nadzwyczajnego pogłębiają znajomość stanów nadzwyczajnych, pozwalają wznieść się ponad «doczesność» konkretnych unormowań i spojrzeć na nie całościowo". M. Brzeziński, Stany nadzwyczajne w polskich konstytucjach, Warszawa 2007, s. 11-12.

${ }^{23}$ Confer P. Marszałek, Polskie prawo stanów szczególnych 1918-1939, Wrocław 2004, s. 29-45. 
Konieczność regulacji stanów nadzwyczajnych w konstytucji jest uzasadniona co najmniej trzema argumentami, warunkującymi bezpieczeństwo, stabilność i rozwój państwa:

1) Wprowadzenie stanu nadzwyczajnego pociąga zazwyczaj ze sobą daleko idące ograniczenie (lub zawieszenie) praw i wolności jednostki gwarantowanych przez konstytucję. Dlatego konstytucja powinna również przewidywać możliwość odejścia od jej postanowień w czasie zagrożenia. Brak unormowań konstytucyjnych w tej materii może doprowadzić do sytuacji, gdy wprowadzenie stanu nadzwyczajnego zostanie wykorzystane do nadużyć.

2) W demokratycznym państwie prawnym wszystkie działania organów władzy publicznej powinny mieć podstawę prawną. Zasada ta dotyczy również sytuacji szczególnego zagrożenia. Brak podstawy prawnej do działania organów władzy publicznej w czasie stanu nadzwyczajnego sprawia, że instytucja ta może zostać wykorzystana niezgodnie z założonym przez ustawę zasadniczą celem.

3) Konstytucyjna możliwość odstąpienia od niektórych zasad ustrojowych kształtujących mechanizm państwowy ma spełniać swoistą rolę odstraszającą szczególnie wobec destrukcyjnych sił wewnętrznych, dążących do obalenia przemocą ustroju demokratycznego. Uwzględniając powyższe argumenty, konieczne jest uregulowanie kwestii stanów nadzwyczajnych w akcie prawnym o randze konstytucji2 ${ }^{24}$.

Aprobując konieczność konstytucyjnej regulacji stanów nadzwyczajnych, nie można pominąć związanych z tym niebezpieczeństw. Zmiany w mechanizmie ustrojowym, które mają obowiązywać w czasie trwania zagrożenia, mogą być trwałe, aby w końcu doprowadzić do obalenia porządku konstytucyjnego. Stąd też ustrojodawca ukraiński powinien ostrożnie podchodzić do problemu stanów nadzwyczajnych. Dlatego pozytywnie należy ocenić fakt, że w konstytucji Ukrainy nie przewiduje się zasadniczych zmian w ustroju państwa w czasie trwania stanu nadzwyczajnego. W konstytucji, regulując szczątkowo omawianą problematykę, odsyła się do bardziej szczegółowych unormowań zawartych w ustawodawstwie zwykłym ${ }^{25}$ - w przeciwieństwie do unormowań stanów nadzwyczajnych w Polsce, gdzie usystematyzowano ją w rozdziale XI konstytucji26.

W konstytucji Ukrainy ${ }^{27}$ ustanowiono trzy rodzaje stanów nadzwyczajnych: stan wojenny, stan wyjątkowy oraz ogłoszenie określonych terenów obszarami nadzwyczajnej sytuacji ekologicznej. Przy czym w konstytucji oraz aktach o niższej randze prawnej nie używa się terminu stan nadzwyczajny w odniesieniu do ogłoszenia określonych terenów Ukrainy obszarami nadzwyczajnej sytuacji ekologicznej. Niemniej

${ }^{24}$ A. Stec, Pozycja ustrojowa prezydenta w systemie konstytucyjnym Ukrainy, Lwów 2014, s. 127.

${ }^{25}$ Podobna systematyka występuje w konstytucjach Francji, Rosji, Holandii, Rumunii, Szwajcarii, Słowacji, Chorwacji, Finlandii i Islandii (E. Kurzępa, Stany nadzwyczajne w polskim porzadku prawnym, Warszawa 2017, s. 55).

${ }^{26}$ Vide szerzej K. Działocha, Stany nadzwyczajne, [w:] Konstytucja Rzeczypospolitej Polskiej. Komentarz, t. IV, red. L. Garlicki, Warszawa 2005, s. 1.

27 Конституція України, Чинне законодавство зі змінами та доповненнями станом на 30 вересня 2016 року (офісійний текст), Київ 2016. 
charakter tej instytucji określony przez ustawodawcę nakazuje zaliczenie jej do stanów nadzwyczajnych. Polskim jej odpowiednikiem jest stan klęski żywiołowej.

Ukraiński ustawodawca nie wyodrębnił stanów nadzwyczajnych w osobnym rozdziale konstytucji, jak to jest np. w polskiej ustawie zasadniczej ${ }^{28}$. Regulacje dotyczące stanów nadzwyczajnych zawarte są w rozdziale II (Prawa, Wolności i Obowiązki Człowieka i Obywatela); rozdziale IV (Rada Najwyższa Ukrainy) oraz rozdziale V (Prezydent Ukrainy). Nie można pominąć stanu wojny, który jest pojęciem prawa międzynarodowe$\mathrm{go}^{29}$. Ukraińskie ustawodawstwo stanu wojny nie zalicza do stanów nadzwyczajnych, jednak ze względu na związek tej instytucji ze stanem wojennym nie można go pominąć przy rozważaniu uprawnień prezydenta (zwłaszcza, że to prezydent jest upoważniony do przedłożenia wniosku do Rady Najwyższej o ogłoszenie stanu wojny).

Termin „stan wojny” pojawia się w art. 85 ust. 9 oraz w art. 106 ust. 19 konstytucji Ukrainy, jak również w art. 13 ust. 4 ustawy o demokratycznej, cywilnej kontroli nad strukturami wojennymi oraz organami ochrony prawnej państwa ${ }^{30}$ (została uchylona 21 czerwca 2018 r.), a także w art. 4 ustawy o obronie Ukrainy. W żadnej z tych ustaw nie podaje się precyzyjnej definicji stanu wojny. Pojęcie stanu wojny należałoby więc zinterpretować jako stan faktyczny, związany z regulowaniem stosunków

${ }^{28}$ Confer M. Safjan, L. Bosek, Konstytucja RP, t. II, Komentarz do art. 87-243, Warszawa 2014, s. $1606-1637$.

${ }^{29}$ Charakter międzynarodowego prawa publicznego regulującego stosunki między państwami oraz sankcje stosowane dla wymuszenia realizacji norm w różnych okresach prowadziły do dyskusji, jak również negacji tej dziedziny prawa. Jednym z krytyków prawa międzynarodowego był A.V. Lundstedt, który napisał: „Prawo narodów po prostu nie istnieje i dlatego każda ze stron może do woli utrzymywać, że prawo jest po jej stronie" (B. Wierzbicki, Materiały do studiów nad prawem międzynarodowym, Białystok 1993, s. 5). Zakorzenione w tradycji prawo międzynarodowe uznawało prawo do użycia siły za jeden z trzech — obok prawa zawierania traktatów i prawa legacji — immanentnych atrybutów suwerenności państwowej. Przez ius ad bellum (prawo do wojny) należy rozumieć prawo do użycia siły w stosunkach międzynarodowych. Pojęcie to należy odróżniać od ius in bello (prawo w wojnie), czyli norm prawnych regulujących metody prowadzenia wojen (J. Barcik, T. Srogosz, Prawo międzynarodowe publiczne, Warszawa 2007, s. 450). Gwarantem bezpieczeństwa zbiorowego na świecie jest m.in. ONZ. System ONZ zbudowany jest na zasadzie bezwzględnego zakazu agresji. Już we wstępie do Karty NZ jest zapisane, że celem członków ONZ jest „,chronić przyszłe pokolenia od klęski wojny”. W art. 1 uznaje się za główny cel ONZ utrzymanie międzynarodowego pokoju i bezpieczeństwa, a w art. 2 ust. 4 stwierdzono, że: „Wszyscy członkowie powinni w swych stosunkach międzynarodowych powstrzymać się od stosowania groźby lub użycia siły przeciwko nietykalności terytorium, albo niepodległości politycznej któregokolwiek państwa, lub wszelkiego innego sposobu, niezgodnego z zasadami Narodów Zjednoczonych.” (W. Góralczyk, S. Sawicki, Prawo międzynarodowe publiczne w zarysie, Warszawa 2009, s. 406). Doświadczenia przy realizacji norm prawa międzynarodowego ujawnią niewydolność systemu bezpieczeństwa ONZ. Ze względu na wydłużony proces decyzyjny np. w NATO lub ONZ prawdopodobnie w przyszłości gwarantem bezpieczeństwa będą dwustronne sojusze wojskowo-polityczne rozwiniętych gospodarczo i militarnie państw.

30 Закон України Про демократичний цивільний контроль над Воєнною організацією і правоохоронними органами держави, Відомості Верховної Ради України (ВВР), 2003, № 46, ст. 366. Із змінами, внесеними згідно із Законами N 4652-VI (4652-17) від 13.04.2012, BBP, 2013, № 21, ст. 208; N 5286-VI (5286-17) від 18.09.2012, BBP, 2013, № 38, ст. 499; N 245-VII (245-18) від 16.05.2013, ВBP, 2014, № 12, ст. 178; N 1697-VII (1697-18) від 14.10.2014, ВBP, 2015, № 2-3, ст. 12; N 2213-VIII (2213-19) від 16.11.2017, ВВР, 2017, № 49-50, ст. 444. 
międzypaństwowych przy użyciu siły ${ }^{31}$. Jest dopuszczalny pod warunkiem uprzedniego zaistnienia stosownych przesłanek bądź określonych sytuacji faktycznych.

W ustawie o obronie Ukrainy (art. 1 ust. 11) pojawia się termin „,czas wojny”, który jest definiowany jako okres od ogłoszenia stanu wojny lub faktycznego rozpoczęcia działań wojennych do zakończenia stanu wojny. Zgodnie z art. 106 pkt 19 konstytucji prezydent wnioskuje do Rady Najwyższej o ogłoszenie stanu wojny w razie zbrojnej agresji na Ukrainę, podejmuje postanowienia o wykorzystaniu sił zbrojnych Ukrainy oraz innych, utworzonych zgodnie z ustawami Ukrainy formacji wojskowych. Art. 4 ust. 1 ustawy o obronie Ukrainy uzupełnia powyższą normę konstytucyjną o zagrożenie napaścią na Ukrainę, co także uzasadnia ogłoszenie stanu wojny oraz wykorzystanie sił zbrojnych. Z kolei zgodnie z art. 85 pkt 9 konstytucji kompetencje Rady Najwyższej Ukrainy obejmują zarządzanie na wniosek prezydenta Ukrainy stanu wojny i zawierania pokoju (sojuszy pokojowych), zatwierdzanie postanowień prezydenta o wykorzystaniu sił zbrojnych oraz innych wojskowych formacji w razie zbrojnej agresji skierowanej przeciw Ukrainie ${ }^{32}$.

W przypadku zbrojnej agresji na Ukrainę (działając na podstawie art. 4 ust. 2 ustawy o obronie Ukrainy) ${ }^{33}$ organy władzy państwowej oraz formacje wojskowe, nie czekając na ogłoszenie stanu wojny, używają wszelkich środków do odparcia agresji. Podstawą prawną do podjęcia działań wojennych jest odpowiedni dekret prezydenta Ukrainy, a nie oficjalne ogłoszenie stanu wojny przez parlament, co pozwala na szybką reakcję na zagrożenia. Wydarzenia „rewolucji godności”, które zdarzyły się w zimie na przełomie 2013 i 2014 r. oraz interwencja służb specjalnych i wojsk FR ${ }^{34}$ na Ukrainie, jak również sprowokowanie wojny informacyjnej w cyberprzestrzeni ${ }^{35}$ wymusiły liczne zmiany $\mathrm{w}$ tej ustawie $\mathrm{w}$ celu przeciwdziałania cyberprzestępstwom, cyberterroryzmowi oraz cyberwojnie na wielu płaszczyznach tzw. wojny hybrydowej, przejawiającej się w różnego rodzaju destrukcji ${ }^{36}$.

31 A. Stec, Pozycja..., s. 128.

32 Confer B. Danieluk, Stany nadzwyczajne, [w:] Publicznoprawne podstawy bezpieczeństwa wewnętrznego, red. M. Zdyb, Warszawa 2014, s. 159.

33 Закон України Про оборону України із змінами, внесеними згідно з Законами № 1420VIII від 16.06.2016, ВВР, 2016, № 31, ст. 46, № 1437-VIII від 07.07.2016, ВВР, 2016, № 33, ст. 564, № 2163-VIII від 05.10.2017, ВВР, 2017, № 45, ст. 403, № 2396-VIII від 05.04.2018, ВВР, 2018, № 21, ст. 194 № 2469-VIII від 21.06.2018, ВВР, 2018, № 31, ст. 241 (Відомості Верховної Ради України BВР, 1992, № 9, ст. 106, ст. 107).

${ }^{34}$ A. Stec, Konflikt na Ukrainie w świetle prawa międzynarodowego publicznego, [w:] Bezpieczeństwo państw Europy Środkowo-Wschodniej w kontekście konfliktu na Ukrainie, red. T. Pączek, Słupsk 2016, s. 171-185.

35 Vide J. Rzuciło, J. Węgrzyn, Stany nadzwyczajne w sytuacji szczególnego zagrożenia państwa w cyberprzestrzeni, „Przegląd Prawa Konstytucyjnego” 2015, nr 5, s. 131-158.

36 Przejawem imperialnej ideologii oraz agresji m.in. na Ukrainie jest tzw. pусский мир (rosyjski świat), który pod hasłami promowania języka, kultury etc. zmierza do odbudowania rosyjskiej strefy wpływów (po upadku ZSRR) przy pomocy narzędzi politycznych, gospodarczych i militarnych, co jest uważane za wzniosły cel przez władze FR. Vide С. Магда, Гібрідна війна: вжити і перемогти, Харків 2015, s. 10-198; M. Szumada, Ukraina jakiej nie znamy, Lwów 2016, s. 180-182. 
Determinatą ogłoszenia stanu wojny może być zbrojna napaść bądź obowiązek wspólnej obrony przeciw agresji ${ }^{37}$, wynikający z umów międzynarodowych. Ogłoszenie stanu wojny wymaga współdziałania prezydenta wnioskującego o ogłoszenie tego stanu oraz Rady Najwyższej, która ogłasza (zarządza) ten stan. Należy zaznaczyć, że ani konstytucja, ani inne ustawy nie podają terminu, w którym parlament ma rozpatrzyć wniosek prezydenta. Powaga sytuacji wymaga niezwłocznego rozpatrzenia wniosku, więc $\mathrm{w}$ takiej sytuacji można by skorzystać $\mathrm{z}$ analogicznego zapisu dotyczącego stanu wojennego, nadzwyczajnego i mobilizacji, bez której trudno wyobrazić sobie wojnę (art. 85 pkt 31 konstytucji Ukrainy), a w tych okolicznościach parlament ma dwa dni na zatwierdzenie decyzji prezydenta.

Postanowienie prezydenta o użyciu sił zbrojnych staje się prawomocne po uzyskaniu zgody Rady Najwyższej, choć niewątpliwie decyzja o ich użyciu należy do jego prerogatyw. Taka regulacja prawna użycia sił zbrojnych Ukrainy ma na celu ograniczenie nadużyć władzy prezydenckiej. Jednak może nastąpić sytuacja, gdy podczas obrony przed zbrojną agresją bądź w celu jej zapobieżenia prezydent użyje sił zbrojnych, a Rada Najwyższa tego nie zaakceptuje. Porozumienia między prezydentem i Radą Najwyższą wymaga także zawarcie pokoju. Rozejm zwykły, a nawet rozejm kapitulacyjny nie kończą stanu wojny. $Z$ reguły stan wojny trwa do wejścia w życie traktatu pokojowego, który podpisuje głowa państwa, a następnie wnioskuje do Rady Najwyższej o jego zatwierdzenie ${ }^{38}$.

Zgodnie z art. 106 pkt 21 konstytucji Ukrainy prezydent w razie konieczności podejmuje decyzje o wprowadzeniu na Ukrainie albo na określonych jej terenach stanu wyjątkowego. Do marca 2000 r. obowiązywała na Ukrainie ustawa o stanie wyjątkowym $^{39}$ z 26 czerwca 1992 r., która nie uwzględniała działań terrorystycznych, specyfiki narodowo-religijnej, jak również geopolitycznej Ukrainy ${ }^{40}$. Od 16 marca 2000 r. zaczęła

${ }^{37} 14$ grudnia 1974 r. Zgromadzenie Ogólne ONZ na 29 posiedzeniu przyjęło rezolucję nr 3314 (XXIX) definiującą pojęcie agresji. Art. 1 stanowi, że agresja to użycie sił zbrojnych przez jedno państwo przeciwko suwerenności, integralności terytorialnej lub politycznej niezawisłości innego państwa lub też użycie ich w inny sposób niezgodny z postanowieniami Karty NZ. Akty agresji obejmują użycie broni przez jedno państwo przeciwko drugiemu państwu, blokadę portów lub wybrzeża danego państwa przez siły zbrojne drugiego, atak sił zbrojnych jednego państwa na lądzie, morzu lub w powietrzu, a także ekspediowanie przez jedno państwo lub w jego imieniu uzbrojonych oddziałów z zamiarem przeprowadzenia działań zbrojnych przeciwko drugiemu państwu. Definicja zawiera katalog działań, które stanowią akty agresji, jednak nie jest on zamknięty, ponieważ Rada Bezpieczeństwa może określić, że również inne akty stanowią agresję w świetle Karty NZ. Należy nadmienić, że definicja przyjęta przez Zgromadzenie Ogólne była wzorowana na konwencji z 1933 r. i nie ma mocy prawnie wiążącej.

${ }^{38}$ Niekiedy stan wojny może być zakończony bez podpisania traktatu pokojowego przez złożenie jednostronnych deklaracji lub nawet przez faktyczne nawiązanie przez państwa wojujące stosunków pokojowych (W. Góralczyk, S. Sawicki, Prawo..., s. 442).

39 Закон України Про надзвичайний стан Відомості Верховної Ради України (ВВР), 1992, № 37 , ст. 538 .

${ }^{40}$ Ustawa ta wyposażała prezydenta w wiele instrumentów prawnych, których mógł używać podczas stanu wyjątkowego. Prezydent mógł uchylać akty prawne organów władzy wykonawczej i samorządu terytorialnego na terenie obowiązywania stanu wyjątkowego oraz podporządkować je sobie, mógł zawiesić działalność organów władzy wykonawczej i samorządu terytorialnego, a w ich miejsce utworzyć 
obowiązywać nowa ustawa o reżimie prawnym stanu wyjątkowego ${ }^{41}$, która unormowała wiele dotychczasowych luk prawnych w tym zakresie. Art. 1 ustawy stanowi, że stan wyjątkowy to szczególny reżim prawny, który może być tymczasowo wprowadzony na Ukrainie lub na określonych jej terenach w przypadku wystąpienia nadzwyczajnej sytuacji z przyczyn technicznych lub w przypadku działań przyrody, która powoduje lub może doprowadzić do śmierci ludzi i strat materialnych, zagrożenia życia i zdrowia obywateli, jak też w sytuacji próby przewrotu państwowego albo zmiany konstytucyjnego ładu Ukrainy z użyciem siły. Stan wyjątkowy przewiduje przyznanie organom władzy państwowej, wojsku oraz organom samorządu terytorialnego określonych w tej ustawie uprawnień niezbędnych dla zażegnania niebezpieczeństwa i zapewnienia bezpieczeństwa państwa oraz ochrony życia i zdrowia obywateli, prawidłowego funkcjonowania gospodarki państwa, organów władzy państwowej i organów samorządu terytorialnego, ochrony ładu konstytucyjnego ${ }^{42}$. Dopuszcza on również wprowadzenie tymczasowych, uwarunkowanych zagrożeniem ograniczeń w realizacji konstytucyjnych praw i wolności człowieka i obywatela oraz ograniczeń praw i interesów osób prawnych w oznaczonym okresie. Nowelizacja ustawy z 12 lutego 2015 r. umożliwiła ponadto użycie reaktywowanej w 2014 r. Ukraińskiej Gwardii Narodowej ${ }^{43}$ dla zabezpieczenia ładu społecznego oraz ochrony życia i zdrowia obywateli.

Pojęcie stanu wyjątkowego definiuje Jewhen Kraweć, twierdząc, że: „wprowadzenie stanu wyjątkowego jest skrajnym, wymuszonym przez okoliczności zaburzeniem wewnętrznej sytuacji w państwie (stanem), w którym stosuje się ograniczenie podstawowych praw i wolności w celu usunięcia szczególnego zagrożenia dla bezpieczeństwa ludności i jej dobrobytu" ${ }^{44}$. Wyjątkiem, który przekłada się na wprowadzenie stanu wyjątkowego, jest sytuacja określona w art. 4 pkt 7 ustawy o reżimie prawnym stanu wyjątkowego, dotycząca masowego przekraczania granicy państwowej $\mathrm{z}$ terytorium państw sąsiednich. Ustawodawca prawdopodobnie miał na celu uregulowanie sytuacji na wypadek zagrożenia konstytucyjnego ustroju i porządku publicznego w państwach sąsiednich, co często prowadzi do masowego przemieszczania się uchodźców z terytorium zagrożonego wojną lub zamieszkami. W tym przypadku

organy nadzwyczajne. W wyjątkowych okolicznościach mógł zostać utworzony specjalny organ odpowiedzialny za zaprowadzenie porządku, a w przypadku katastrof o charakterze ekologicznym prezydent mógł skorzystać z sił zbrojnych Ukrainy. Vide szerzej A. Stec, Polska i Ukraina na tle zmian w uktadzie geopolitycznym, „Studia nad Bezpieczeństwem” 2017, nr 2, s. 119-127.

41 Закон України Про правовий режим надзвичайного стану Відомості Верховної Ради України (ВВР), 2000, № 23, ст. 176.

${ }^{42}$ Mimo że w art. 1 cytowanej ustawy nie wspomina się wyraźnie, że stan wyjątkowy chroni przed wewnętrznym zagrożeniem państwa, to $\mathrm{z}$ charakteru wymienionych w nim dóbr (ład konstytucyjny Ukrainy, życie i zdrowie obywateli etc.) wynika, że faktycznie dotyczy zagrożeń wewnętrznych, a nie zewnętrznych, gdyż do obrony przed zagrożeniem zewnętrznym powołany jest stan wojenny (A. Stec, Pozycja..., s. 132).

43 Закон України Про Національну гвардію України Відомості Верховної Ради (ВВР) 2014, № 17, ст. 594.

${ }^{44}$ Е. Кравець, Національна безпека Украӥни:права людини в умовах надзвичайного стану, Київ1998, s. 38. 
destabilizacja jednego państwa lub kilku państw mogłaby spowodować destabilizację Ukrainy, czemu ustawodawca chciałby zapobiec.

Instytucja stanu wyjątkowego jest szczególną formą sprawowania władzy przez organy władzy publicznej. Na podstawie konstytucji następuje ograniczenie praw i wolności osób fizycznych i prawnych oraz są nakładane na nie dodatkowe obowiązki związane z zabezpieczeniem porządku publicznego ${ }^{45}$. W literaturze wyróżnia się zasady ogólne stanów nadzwyczajnych dotyczące: ostateczności, legalności, proporcjonalności, celowości, tymczasowości, ochrony podstaw systemu prawnego oraz ochrony organów przedstawicielskich ${ }^{46}$. Dokonując analizy przesłanek wprowadzenia stanu wyjątkowego na Ukrainie, możemy stwierdzić, że są to przesłanki niedookreślone, pozostawiające swobodę interpretacyjną. Wyłania się duża ogólnikowość w ich sformułowaniu, choć musimy pamiętać, że nie można dokładnie przewidzieć charakteru zagrożenia. Takie próby z góry skazane byłyby na niepowodzenie i w praktyce mogłyby uniemożliwić wprowadzenie stanu wyjątkowego w sytuacji kryzysowej. Trudno w tej sytuacji nie przychylić się do twierdzenia Krzysztofa Prokopa, że: ,[...] zbyt ścisłe określenie przesłanek wprowadzenia stanu wyjątkowego powoduje zagrożenie wolności i praw człowieka i obywatela bez formalnego wprowadzenia stanu nadzwyczajnego. Generalność przesłanek wprowadzenia stanu wyjątkowego narusza z jednej strony gwarancję, że nie zostanie on wprowadzony w sytuacjach rzeczywiście tego wymagających, ale z drugiej strony chroni wolności i prawa człowieka i obywatela przed nadmiernym naruszaniem w sytuacjach normalnych" ${ }^{47}$. Szczególnego znaczenia nabiera stwierdzenie Karla Loewensteina, że ,[...] jest niemożliwe znalezienie prawnie ujętych kryteriów dla okoliczności, w świetle których powstaje kryzys lub sytuacja zagrożenia usprawiedliwiająca lub nawet czyniąca niezbędnym wprowadzenie stanu nadzwyczajnego"48.

Ogólnikowość przesłanek wprowadzenia stanu wyjątkowego stwarza spore problemy interpretacyjne i pozostawia duży stopień uznaniowości organom wprowadzającym stan wyjątkowy ${ }^{49}$. Prawidłowa legislacja wymaga, aby ustrojodawca usystematyzował stany nadzwyczajne począwszy od tych powodujących najdalej idące konsekwencje w funkcjonowaniu państwa, a zakończył na ogłoszeniu określonych terenów obszarami nadzwyczajnej sytuacji ekologicznej, co niesie ze sobą najmniejsze dolegliwości. W konstytucji Ukrainy rezygnowano z określenia przesłanek wprowadzenia stanu wyjątkowego, stwierdzając, że może on zostać wprowadzony „w razie konieczności” (art. 106 pkt 21). Kryteria wprowadzenia stanu wyjątkowego określa natomiast art. 4 ustawy o reżimie prawnym stanu wyjątkowego ${ }^{50}$.

${ }^{45}$ Confer G. Agamben, Stan wyjątkowy, Kraków 2008, s. 40-117.

${ }^{46}$ K. Działocha, uwagi do art. 228 konstytucji, [w:] Konstytucja Rzeczypospolitej Polskiej. Komentarz, t. IV, red. L. Garlicki, Warszawa 2005, s. 1-17.

${ }^{47}$ K. Prokop, Stany..., s. 75.

${ }^{48}$ K. Loewenstein, Verfassungslehre, Tübungen 1968, s. 223.

49 „Więź” 1988, nr 11-12, s. 101 i n.

${ }^{50}$ Obejmują one: 1) wystąpienie masowych ataków terrorystycznych, które prowadzą do śmierci wielu osób lub zniszczenia ważnych obiektów użyteczności społecznej; 2) wystąpienie konfliktów etnicznych i religijnych, prowadzenie strajków okupacyjnych w strategicznych obiektach lub miejscowościach, co zagraża 
Głowa państwa podejmuje decyzję o wprowadzeniu stanu wyjątkowego, ogłaszając ją w dekrecie ${ }^{51}$, jednak dla swej ważności wymaga ona kontrasygnaty premiera i ministra odpowiedzialnego za akt i jego wykonanie ${ }^{52}$. Kontrasygnata zgodnie z opinią Wiktora Melaszczenki ma na celu de facto i de iure przenieść polityczną (lecz nie prawną) odpowiedzialność za przyjęty akt prawny głowy państwa na osoby, które go także podpisały ${ }^{53}$.

Po podpisaniu dekretu o wprowadzeniu stanu wyjątkowego prezydent Ukrainy przedkłada ten akt do zatwierdzenia Radzie Najwyższej, która rozpatruje go jako pilny (poza kolejnością) i zgodnie z art. 85 pkt 31 konstytucji ma dwa dni na jego rozpatrzenie $^{54}$. W sytuacji, którą normuje art. 83 ust. 3 konstytucji, tj. w razie ogłoszenia dekretu o wprowadzeniu stanu wyją̧tkowego czy też wojennego, Rada Najwyższa zbiera się na posiedzenie w terminie dwóch dni bez jego zwoływania - ma to na celu ograniczenie ewentualnych nadużyć głowy państwa w okresie między sesjami parlamentu ${ }^{55}$.

Wprowadzenie stanu wyjątkowego na podstawie art. 4 pkt 2-7 ustawy o reżimie prawnym stanu wyjątkowego nakazuje prezydentowi zwrócenie się przez środki

bezpieczeństwu obywateli oraz narusza funkcjonowanie organów władzy państwowej i samorządu terytorialnego; 3) wystąpienia nadzwyczajnych sytuacji z przyczyn technicznych lub w wyniku działań przyrody: klęski żywiołowe, katastrofy, epidemie, duże pożary, które stwarzają zagrożenie dla życia i zdrowia dużej liczby ludności; 4) masowe demonstracje i strajki naruszające porządek publiczny, charakteryzujące się przemocą i ograniczeniem praw i wolności obywateli; 5) masowe przechodzenie przez granicę państwa z terenów sąsiadujących państw; 6) próby przewrotu państwowego lub zmiany konstytucyjnego ładu Ukrainy w drodze siły; 7) wymóg odnowienia porządku konstytucyjnego oraz funkcjonowania organów władzy państwowej w sytuacji naruszeń.

${ }^{51}$ Dekret o wprowadzeniu stanu wyjątkowego powinien zawierać: 1) uzasadnienie konieczności jego wprowadzenia zgodnie $\mathrm{z}$ art. 4 ustawy o reżimie prawnym stanu wyjątkowego; 2) zasięg terytorialny jego obowiązywania; 3) dokładny czas wprowadzenia oraz okres, na jaki jest wprowadzany; 4) katalog i granice szczególnych działań, wyczerpujący zakres konstytucyjnych praw i wolności, które zostają ograniczone w związku $z$ wprowadzeniem stanu wyjątkowego oraz zakres tymczasowych ograniczeń praw i ustawowych interesów osób prawnych z zaznaczeniem okresu obowiązywania tych ograniczeń; 5) organy władzy państwowej, wojsk i samorządu terytorialnego, którym przyznano specjalne uprawnienia w zakresie realizacji stanu wyjątkowego oraz zakres ich dodatkowych uprawnień.

52 О. Совгиря, Н. Шукліна, Конституиіийне право України, повний курс, Київ 2012, s. 349-350.

53 В. Молдован, В. Мелащенко, Конституиіийне право. Словник-довідник, Київ 1996, s. 210.

${ }^{54}$ Rada Najwyższa może przyjąć dekret w całości, częściowo z rekomendacjami lub zastrzeżeniami albo uchylić projekt ustawy o zatwierdzeniu dekretu prezydenta Ukrainy o wprowadzeniu stanu wojennego, wyjątkowego na Ukrainie albo na określonym jej obszarze, dotyczy to także mobilizacji i ogłoszenia określonych terenów obszarami nadzwyczajnej sytuacji ekologicznej. Jeżeli Rada Najwyższa zatwierdziła ustawą stosowny dekret prezydenta, częściowo z rekomendacjami lub zastrzeżeniami, to obowiązują te normy dekretu, które zostały zatwierdzone przez parlament. Stosowny dekret wchodzi w życie po zatwierdzeniu go przez parlament i niezwłocznym opublikowaniu. Musi być także niezwłocznie ogłoszony w środkach masowego przekazu lub w inny sposób. W przypadku niezatwierdzenia przez Radę Najwyższą projektu ustawy dotyczącej stosownego dekretu nie wchodzi on w życie. O przyjętym stanowisku w stosunku do konkretnego dekretu przewodniczący Rady Najwyższej niezwłocznie informuje prezydenta Ukrainy i społeczeństwo m.in. przez środki masowego przekazu (В. Теліпко, Конституиійне та конститучійно - процесуальне право Украӥни, Київ 2009, s. 322).

${ }^{55}$ Art. 83 ust. 4 stanowi, że w razie ustania pełnomocnictw Rady Najwyższej w czasie obowiązywania stanu wojennego lub wyjątkowego jej pełnomocnictwa zostają przedłużone do dnia pierwszego posiedzenia pierwszej sesji Rady Najwyższej, wybranej po zakończeniu stanu wojennego lub nadzwyczajnego. 
masowego przekazu lub w inny sposób do grup osób, organizacji, zakładów (inicjatorów czy też uczestników działań), które mogą być powodem wprowadzenia stanu wyjątkowego z żądaniem zaniechania działań sprzecznych z prawem. W swojej odezwie prezydent wyznacza okres, w jakim wskazane podmioty mają zastosować się do obowiązujących przepisów, z uprzedzeniem o możliwości wprowadzenia stanu wyjątkowego. W przypadku zaistnienia sytuacji, która wymaga podjęcia niezwłocznych działań w celu ratowania życia wielu osób, stan wyjątkowy może zostać wprowadzony bez wezwania wskazanego na początku niniejszego akapitu ${ }^{56}$.

Propozycję wprowadzenia stanu wyjątkowego na Ukrainie (ewentualnie na określonym jej terytorium) przedkłada prezydentowi Rada Narodowego Bezpieczeństwa i Obrony Ukrainy. Prezydent może działać także na podstawie danych przekazanych przez organy wywiadu, którym kieruje i którego działalność koordynuje (art. 7 ustawy o organach wywiadu Ukrainy) ${ }^{57}$. W razie konieczności wprowadzenia tego stanu na podstawie art. 4 pkt 1 ustawy o reżimie prawnym stanu wyjątkowego (tj. wystąpienia nadzwyczajnych sytuacji z przyczyn technicznych lub w wyniku działań przyrody obejmujących: klęski żywiołowe, katastrofy, duże pożary, epidemie, które stwarzają zagrożenie dla życia i zdrowia dużej liczby ludności) propozycję przedkłada Gabinet Ministrów Ukrainy. Wprowadzenie stanu wyjątkowego na terytorium Autonomicznej Republiki Krymu [dalej: ARK] albo części jej terytorium może zainicjować również Rada Najwyższa Autonomicznej Republiki Krymu (art. 5 ust. 5$)^{58}$.

Stan wyjątkowy na całym terytorium Ukrainy może być wprowadzony na okres nie dłuższy niż 30 dni, natomiast na części jej terytorium do 60 dni. Istnieje możliwość przedłużenia okresu trwania stanu wyjątkowego dekretem prezydenta maksymalnie o $30 \mathrm{dni}$ (dekret wchodzi w życie po jego zatwierdzeniu przez Radę Najwyższą) ${ }^{59}$. O wcześniejszym odwołaniu stanu wyjątkowego decyduje prezydent, jeżeli zostały usunięte przesłanki, które spowodowały konieczność wprowadzenia tego stanu. Może on podjąć

${ }^{56}$ Warto zwrócić uwagę na polskie regulacje prawne w tym zakresie, które obligują redaktorów naczelnych dzienników oraz nadawców programów radiowych i telewizyjnych — na żądanie ministra, wojewodów, starostów, prezydentów miast albo ich pełnomocników - do nieodpłatnego, niezwłocznego publikowania lub zamieszczania komunikatów tych organów związanych z działaniami w celu zapobieżenia skutkom stanów nadzwyczajnych lub ich usunięcia.

57 Закон України Про розвідувальні органи України Відомості Верховної Ради України (ВВР), 2001, № 19, ст. 94. Із змінами, внесеними згідно із Законами № 2505-IV від 25.03.2005, ВBР, 2005, № 17, № 18-19, ст. 267; № 3200-IV від 15.12.2005, ВВР, 2006 № 14, ст. 116 № 328-V від 3.11.2006, ВBP, 2006, № 51, ст. 519 № 489-V від 19.12.2006, ВBР, 2007; № 7-8, ст. 66; № 107-VI від 28.12.2007, BBP, 2008, № 5-6, № 7-8, ст. 78; № 309-VI від 3.06.2008, ВBР, 2008, № 27-28, ст. 253; № 2526-VI від 21.09.2010, ВBР, 2011, № 4, ст. 27; № 5040-VI від 4.07.2012, ВBР, 2013, № 25, ст. 246; № 267-VIII від 19.03.2015, ВBР, 2015, № 22, ст. 151; № 901-VIII від 23.12.2015, ВBР, 2016, № 4, ст. 44; № 1437-VIII від 7.07.2016, ВВР, 2016, № 33, ст. 564; № 2163-VIII від 5.10.2017, ВBР, 2017, № 45, ст. 403.

${ }_{58}$ Po nielegalnej aneksji Krymu przy użyciu siły zbrojnej w 2014 r. przez FR i tzw. jednostronnym proklamowaniu niepodległości przez Krym 17 marca 2014 r. Rada Najwyższa Republiki Autonomicznej Krymu podjęła bezprawną decyzję o przekształceniu się w Radę Państwową Republiki Krymu (ukr. Державна Рада Республіки Крим). W następstwie czego norma ta nie będzie na pewno w najbliższym czasie egzekwowana.

59 A. Stec, Pozycja..., s. 135. 
decyzję samodzielnie bądź na wniosek parlamentu. Wnioskować o wcześniejsze odwołanie stanu wyjątkowego może również Rada Najwyższa Autonomicznej Republiki Krymu, gdyby dotyczył jej terytorium, oraz Gabinet Ministrów Ukrainy w omawianych już sytuacjach siły wyżzzej dotyczących art. 4 pkt 1 tejże ustawy.

$\mathrm{Na}$ podstawie art. 13 ustawy o reżimie prawnym stanu wyjątkowego prezydent Ukrainy dekretem może nadać dodatkowe uprawnienia organom władzy państwowej, niezbędne do normalizacji życia i przywrócenia porządku konstytucyjnego. W art. 14 tej ustawy ustawodawca wymienia podmioty, które mogą wydawać akty prawne (postanowienia, rozporządzenia, rozkazy, dyrektywy) dotyczące stanu wyjątkowego w granicach swych kompetencji na określonym terenie, które podlegają niezwłocznemu wykonaniu. Ustawodawca przewiduje także możliwość powołania tzw. sztabów operacyjnych, złożonych z wyspecjalizowanych służb, które także mogą wydawać akty prawne do likwidacji zagrożeń przewidzianych przez stan wyjątkowy.

Zakres dopuszczalnych ingerencji w prawa i wolności jednostki ${ }^{60}$ jest wyznaczony klauzulą negatywną, gdyż art. 64 ust. 2 konstytucji wskazuje, że w warunkach stanu wyjątkowego (także wojennego) nie mogą być ograniczone prawa i wolności określone w: art. 24 - równość wobec prawa, zakaz dyskryminacji jednostki; art. 25 — zakaz pozbawienia obywatelstwa oraz wydalenia lub wydania obywatela innemu państwu; art. 27 - prawo do ochrony życia; art. 28 - zasada nienaruszalności i poszanowania godności człowieka oraz wymóg zgody na eksperyment naukowy; art. 29 — gwarancja nietykalności i wolności osobistej; art. 40 - prawo składania petycji, wniosków i skarg; art. 47 - pomoc w zaspokajaniu potrzeb mieszkaniowych obywateli oraz ochrona praw lokatorów; art. 51 — zasada opieki państwa nad rodziną; art. 52 — ochrona dzieci; art. 55 — zasada poszanowania i ochrony wolności człowieka oraz prawo do sądu; art. 56 - prawo do odszkodowania; art. 57 - prawo obywateli do informacji o działalności organów władzy publicznej w tym o przysługujących im prawach i obowiązkach; art. 58 — zakaz retroaktywności prawa z wyjątkiem przypadków łagodzących lub uchylających odpowiedzialność jednostki (w tym zasada przyzwoitej legislacji); art. 59 - prawo do obrony; art. 60 - zakaz nakłaniania do przestępstw; art. 61 — zakaz podwójnego karania za ten sam czyn; art. 62 — zasada domniemania niewinności i rekompensaty w przypadku bezpodstawnego skazania oraz w art. 63 konstytucji — prawo do odmowy składania zeznań przeciw najbliższym ${ }^{61}$. Natomiast w warunkach stanu wojennego lub wyjątkowego można ustanawiać dalsze ograniczenia pozostałych praw i wolności z określeniem czasu trwania tych ograniczeń ${ }^{62}$. Warto wskazać, że konstytucje takich państw europejskich jak Belgia, Austria, Włochy,

${ }^{60}$ Confer A. Kustra, Stany nadzwyczajne, [w:] Prawo konstytucyjne, red. Z. Witkowski, Toruń 2013, s. $698-699$.

${ }^{61}$ Szczegółowość regulacji stanów nadzwyczajnych wynika zazwyczaj z doświadczeń historycznych danego państwa i postrzeganej potrzeby dokonania regulacji stanów nadzwyczajnych w takim stopniu szczegółowości, jaki wydaje się zasadny. (J. Jaskiernia, Akty normatywne w stanach nadzwyczajnych, [w:] Konstytucyjny system źródet prawa, red. A. Szmyt, Warszawa 2005, s. 138).

62 В. Федоренко, Конституиійне Право України, Підручник, Київ 2016, s. 262. 
Luksemburg, Norwegia i Czechy nie zawierają uregulowań dotyczących stanów nadzwyczajnych ${ }^{63}$.

Dla zabezpieczenia interesów narodowego bezpieczeństwa na podstawie dekretu prezydenta o wprowadzeniu stanu wyjątkowego mogą być nałożone następujące ograniczenia: wjazdu i wyjazdu oraz przemieszczania się po terytorium Ukrainy, wzmocnienie ochrony porządku publicznego, zakaz masowych demonstracji, zakaz strajków. W sytuacji zaistnienia nadzwyczajnych okoliczności związanych z przyczynami zagrożeń technicznych i przyrodniczych może zostać przeprowadzona ewakuacja, kwarantanna, wprowadzenie reglamentacji towarów konsumpcyjnych oraz różne ograniczenia w działalności gospodarczej ${ }^{64}$.

W ustawie nie przewidziano rozszerzenia kompetencji prezydenta Ukrainy w czasie obowiązywania stanu wyjątkowego. W art. 21 ustawy o reżimie prawnym stanu wyjątkowego są wprowadzone zakazy, które mają na celu zapewnienie ładu prawnego w tym stanie nadzwyczajnym: zakaz zmiany konstytucji Ukrainy i Autonomicznej Republiki Krymu, zakaz zmian w ustawach wyborczych, zakaz przeprowadzania wyborów prezydenta Ukrainy, wyborów do parlamentu Ukrainy i parlamentu ARK oraz organów samorządu terytorialnego. O wprowadzeniu stanu wyjątkowego na Ukrainie musi być poinformowany sekretarz generalny ONZ.

Ukraiński ustawodawca (uwzględniając tragiczne doświadczenia m.in. największą katastrofę w historii energetyki jądrowej w Czarnobylu, powodzie, katastrofy lotnicze) zdecydował o wyodrębnieniu trzeciego stanu nadzwyczajnego — ogłoszenia określonych terenów obszarami nadzwyczajnej sytuacji ekologicznej. Synonimem tego stanu nadzwyczajnego w Polsce jest stan klęski żywiołowej. W konstytucji Ukrainy nie określono przesłanek wprowadzenia tego stanu, ograniczając się do stwierdzenia w art. 21, że prezydent ogłasza w razie konieczności określone tereny obszarami nadzwyczajnej sytuacji ekologicznej, co następnie zatwierdza Rada Najwyższa.

Ustawa o obszarze nadzwyczajnej sytuacji ekologicznej ${ }^{65} \mathrm{w}$ art. 1 ust. 2 zawiera definicję nadzwyczajnej sytuacji ekologicznej — jest to sytuacja, w której na określonych terenach nastąpiły negatywne zmiany $\mathrm{w}$ środowisku naturalnym wymagające nadzwyczajnej interwencji ze strony państwa. Negatywne zmiany w środowisku naturalnym to katastrofy, które ograniczają lub wykluczają funkcjonowanie człowieka oraz prowadzenie działalności gospodarczej na określonym obszarze. Podstawą do ogłoszenia terenu obszarem nadzwyczajnej sytuacji ekologicznej jest zanieczyszczenie środowiska przyrodniczego przekraczające wyznaczone przez przepisy normy; realne zagrożenie życia i zdrowia dużej liczby osób; zwiększenie zachorowalności populacji na skutek zmian $w$ środowisku naturalnym ${ }^{66}$. Problematykę stanu nadzwy-

${ }^{63}$ E. Kurzępa, Stany..., s. 54.

${ }^{64}$ A. Stec, Pozycja..., s. 136.

65 Закон України Про зону надзвичайної екологічної ситуації Відомості Верховної Ради України (ВВР), 2000, № 42, ст. 348 Із змінами, внесеними згідно із Законами № 3421-IV (3421-15) від 9.02.2006, (ВВР), 2006, N 22, ст. 199 № 901-VIII (901-19) від 23.12.2015, ВBР, 2016, № 4, ст. 44.

${ }^{66}$ A. Stec, Pozycja..., s. 137. 
czajnego w postaci ogłoszenia określonych terenów obszarami nadzwyczajnej sytuacji ekologicznej regulują także ustawa o ochronie środowiska przyrodniczego ${ }^{67}$, ustawa o służbie awaryjno-ratowniczej ${ }^{68}$, która obowiązywała do 2 października 2012 r., gdy zastąpił ją kodeks obrony cywilnej Ukrainy ${ }^{69}$, uchylając zarazem ustawę o obronie cywilnej Ukrainy ${ }^{70}$. Analizując liczne zmiany w ustawodawstwie ukraińskim w zakresie tego stanu nadzwyczajnego, można zaobserwować wzmocnienie pozycji Gabinetu Ministrów kosztem prezydenta Ukrainy, choć to właśnie głowa państwa podejmuje decyzję ogłoszeniu określonych terenów obszarami nadzwyczajnej sytuacji ekologicznej ${ }^{71}$. Decyzja prezydenta w tym zakresie obwarowana jest obowiązkiem kontrasygnaty

67 Закон України Про охорону навколишнього природного середовища Відомості Верховної Ради України (ВВР), 1991, № 41, ст. 546. Із змінами, внесеними згідно із Законами № 3180-XII від 5.05.93, ВВР, 1993, № 26, ст. 277; № 81/96-ВР від 6.03.96, ВВР, 1996, № 15, ст. 70; № 650/97-ВР від 19.11.97, ВВР, 1998, № 11-12, ст. 41; № 186/98-ВР від 5.03.98, ВBР, 1998, № 34, ст. 230 № 783-XIV від 30.06.99, ВВР, 1999, № 34, ст. 274; № 934-XIV від 14.07.99, ВBР, 1999, № 38, ст. 338;№ 1287-XIV від 14.12.99, ВВР, 2000, № 4, ст. 26; № 1288-XIV від 14.12.99, ВВР, 2000, № 5, ст. 34 № 1642-III від 6.04.2000, ВВР, 2000, № 27, ст. 213; № 1807-III від 8.06.2000, ВВР, 2000, № 38, ст. 318; № 2556-III від 21.06.2001, ВВР, 2001, № 26, ст. 176 № 198-IV від 24.10.2002, ВВР, 2002, № 50, ст. 366; № 254-IV від 28.11.2002, ВВР, 2003, № 4, ст. 31 № 380-IV від 26.12.2002, ВВР, 2003, № 10-11, ст. 86; № 762-IV від 15.05.2003, ВВР, 2003, № 30, ст. 247 № 824-IV від 22.05.2003, ВВР, 2003, № 35, ст. 269; № 1122-IV від 11.07.2003, ВВР, 2004, № 7, ст. 58 № 1344-IV від 27.11.2003, ВВР, 2004, № 17-18, ст. 250; № 1863-IV від 24.06.2004, ВВР, 2004, № 27, ст. 362; № 3235-IV від 20.12.2005, ВBР, 2006, № 9, № 10-11, ст. 96; № 3421-IV від 9.02.2006, ВBР, 2006, № 22, ст. 199; № 489-V від 19.12.2006, ВВР, 2007, № 7-8, ст. 66; № 997-V від 27.04.2007, ВВР, 2007, № 33, ст. 440; № 1026-V від 16.05.2007, ВВР, 2007, № 27-28, ст. 253; № 515-VІ від 17.09.2008, ВВР, 2008, № 52, ст. 394; № 882-VІ від 15.01.2009, ВВР, 2009, № 24, ст. 297; № 1158-VI від 19.03.2009, ВВР, 2009, № 30, ст. 428; № 2457-VI від 8.07.2010, ВBP, 2010, № 48, ст. 564; № 2756-VI від 2.12.2010, ВВР, 2011, № 34, ст. 343; № 3530-VI від 16.06.2011, ВВР, 2012, № 2-3, ст. 3; № 4713-VI від 17.05.2012, ВBР, 2013, № 8, ст. 77; № 1193-VII від 9.04.2014, ВBР, 2014, № 23, ст. 873; № 1697-VII від 14.10.2014, ВВР, 2015, № 2-3, ст. 12; № 71-VIII від 28.12.2014, ВВР, 2015, № 7-8, № 9, ст. 55; № 77-VIII від 28.12.2014, ВВР, 2015, № 11, ст. 75.

68 Закон України Про аварійно-рятувальні служби Відомості Верховної Ради України (ВВР), 2000, N 4, ст. 25 Із змінами, внесеними згідно із Законами N 2171-III (2171-14) від 21.12.2000, ВBР, 2001, № 9, ст. 38 N 3370-IV (3370-15) від 19.01.2006, ВBP, 2006, № 22, ст. 184, № 587-VI (587-17) від 24.09.2008, ВВР, 2009, № 9, ст. 117 N 2555-VI (2555-17) від 23.09.2010, ВВР, 2011, № 6, ст. 41 N 5081-VI (5081-17) від 5.07.2012, ВBР, 2013, № 30, ст. 340 N 5459-VI (5459-17) від 16.10.2012, ВВР, 2013, № 48, ст. 682 .

${ }^{69}$ Кодекс цивільного захисту України, Відомості Верховної Ради (ВВР), 2013, № 34-35, ст. 458. Із змінами, внесеними згідно із Законами: № 224-VII від 14.05.2013, ВВР, 2014, № 11, ст. 132; № 353-VII від 20.06.2013, ВBР, 2014, № 13, ст. 221; № 1166-VII від 27.03.2014, BBР, 2014, № 20-21, ст. 745 № 76-VIII від 28.12.2014, ВВР, 2015, № 6, ст. 40; № 124-VIII від 15.01.2015, ВВР, 2015, № 14, ст. 96; № 766-VIII від 10.11.2015, ВВР, 2015, № 52, ст. 482; № 1404-VIII від 2.06.2016, ВВР, 2016, № 30, ст. 542; № 2020-VIII від 13.04.2017, ВВР, 2017, № 22, ст. 257; № 2581-VIII від 2.10.2018, ВВР, 2018, № 46, ст. 371.

70 Закон України Про Цивільну оборону України, Відомості Верховної Ради України (ВВР), 1993, № 14, ст. 124, № 2975-XII (2975-12) від 3.02.93, ВВР, 1993, № 14, ст. 125, Із змінами, внесеними згідно із Законами № 555-XIV (555-14) від 24.03.99, BВР, 1999, № 19, ст. 171 N 2470 -III (2470-14) від 29.05.2001, ВВР, 2001, № 32, ст. 172 № 1419-IV (1419-15) від 3.02.2004, BВР, 2004, № 19, ст. 259 № 1014-V (1014-16) від 11.05.2007, ВBР, 2007, N 33, ст. 442.

71 О. Совгиря, Конституційно-правовий статус Кабінету Міністрів Украӥни: стан та тендениї розвитку, Київ 2012, s. 201. 
i przybiera formę dekretu. Zgodnie z art. 6 ust. 1 ustawy o obszarze nadzwyczajnej sytuacji ekologicznej propozycję ogłoszenia tego stanu przez prezydenta składa Rada Bezpieczeństwa Narodowego i Obrony Ukrainy ${ }^{72}$ lub wnioskuje o to Gabinet Ministrów Ukrainy. Dekret prezydenta o ogłoszeniu określonych terenów obszarami nadzwyczajnej sytuacji ekologicznej jest zatwierdzany przez Radę Najwyższą w ciągu dwóch dni od jego zarządzenia. Ogłoszenie następuje niezwłocznie poprzez środki masowego przekazu oraz system ostrzegawczy obrony cywilnej. Wcześniejsze zakończenie tego stanu nadzwyczajnego mogą sygnalizować te same organy (RBNiOU, Gabinet Ministrów Ukrainy, Rada Najwyższa ARK), które proponują jego ogłoszenie w razie usunięcia zagrożenia i normalizacji sytuacji ${ }^{73}$.

Zgodnie z art. 10 ust. 5 ustawy o obszarze nadzwyczajnej sytuacji ekologicznej istnieje możliwość jednoczesnego wprowadzenia na terenach ogłoszonych obszarami nadzwyczajnej sytuacji ekologicznej stanu wyjątkowego zgodnie z ustawą o reżimie prawnym stanu wyjątkowego. Zapewnienie porządku publicznego w czasie trwania tej klęski żywiołowej spoczywa na formacjach Ministerstwa Spraw Wewnętrznych oraz Służbie Bezpieczeństwa - transformowanych formacjach o radzieckim rodowodzie, które podjęły szereg niechlubnych działań w okresie od listopada 2013 r. do lutego 2014 r. w trakcie masowych protestów określanych mianem „rewolucji godności”. W systemie komunistycznym zaliczały się one do organów ochrony prawa.

\section{STAN WOJENNY NA UKRAINIE 26 LISTOPAD-26 GRUDZIEŃ 2018 R.}

Instytucja stanu wojennego na Ukrainie w latach 1991-2013 była omawiana w ukraińskiej literaturze prawniczej czysto hipotetycznie, jednak konflikt zbrojny w Gruzji (2008 r.) stanowił preludium do agresji w 2014 r. Rosji na Ukraiński Donbas i Krym. Nieformalna mobilizacja wojsk Federacji Rosyjskiej (po agresji) na zajętych terenach oraz wzdłuż granicy z Ukrainą doprowadziła do sytuacji, gdy wprowadzenie stanu wojennego było tylko kwestią czasu. Jednak wprowadzenie stanu wojennego nie zależało jedynie od przesłanek prawnych bądź woli politycznej kierownictwa państwa, ale od okoliczności i potencjału obronnego. Art. 106 pkt 20 konstytucji określa dwie przesłanki wprowadzenia stanu wojennego: groźba napaści oraz zagrożenie niepodległości państwowej. Prawo wprowadzenia stanu wojennego przysługuje prezydentowi, który może podjąć decyzję o powszechnej albo częściowej mobilizacji. Uprawnienie prezydenta uznawane jest za wynikające z jego szczególnej odpowiedzialności za sprawy suwerenności i integralności państwa. Zarządzenie stanu wojennego przez prezydenta przybiera formę dekretu, który nie potrzebuje dla swej ważności kontrasygnaty. Stan wojenny na Ukrainie może obejmować całe terytorium państwa albo jego wyodrębniony obszar. Z kolei na podstawie art. 85 pkt 31 konstytucji uprawnienia Rady Najwyższej obejmują zatwierdzenie w ciągu dwóch dni od momentu zarządzenia przez prezydenta Ukrainy dekretów o wprowadzeniu stanu wojennego lub wyjątkowego na Ukrainie bądź

72 Закон України Про Раду національної безпеки і оборони України Відомості Верховної Ради України (ВВР), 1998, № 35, ст. 237.

${ }^{73}$ A. Stec, Pozycja..., s. 138. 
na określonych jej terenach, o ogłoszeniu powszechnej albo częściowej mobilizacji oraz o ogłoszeniu określonych terenów obszarami nadzwyczajnej sytuacji ekologicznej ${ }^{74}$.

Ustawa o obronie Ukrainy ${ }^{75}$ w art. 1 ust. 12 uszczegóławia konstytucyjną definicję stanu wojennego jako szczególnego reżimu prawnego wprowadzanego na Ukrainie lub na określonych jej terenach w razie agresji zbrojnej, groźby napaści zbrojnej, zagrożenia niepodległości państwowej Ukrainy lub integralności terytorialnej, przewidującego przyznanie organom władzy państwowej, wojsku i organom samorządu terytorialnego uprawnień, koniecznych do zażegnania niebezpieczeństwa i zapewnienia bezpieczeństwa państwu. Stan wojenny zakłada tymczasowe, warunkowe ograniczenie praw i wolności człowieka i obywatela oraz praw i ustawowych interesów osób prawnych z zaznaczeniem okresu trwania tych ograniczeń ${ }^{76}$. Przewiduje on nadanie odpowiednim organom władzy państwowej, dowództwu wojsk lub organom samorządu terytorialnego kompetencji niezbędnych do odparcia powstałych zagrożeń ${ }^{77}$.

Uwzględniając polskie doświadczenia oraz kontrowersje towarzyszące wprowadzeniu stanu wojennego 13 grudnia 1981 r. $^{78}$, ukraiński ustawodawca powinien doprecyzować w swoim ustawodawstwie ogólne zasady stanu wojennego ze szczególnym uwzględnieniem zasady proporcjonalności (działań organów władzy w procesie podejmowania decyzji, ich odpowiedzialności oraz zgodności z konstytucją aktów prawnych wydawanych w czasie stanu wojennego ) i celowości (aby środki podejmowane w ramach stanu wojennego zmierzały do przywrócenia normalnego funkcjonowania państwa i realizacji przez obywateli ich praw i wolności) oraz adekwatnych działań w odpowiedzi na wojskową agresję na ukraiński Donbas i Krym, jak również gromadzenie rosyjskich inwazyjnych sił zbrojnych wzdłuż granic z Ukrainą.

W dniu 25 listopada 2018 r. na wodach międzynarodowych Cieśniny Kerczeńskiej okręty wojenne oraz lotnictwo FR otworzyły ogień do trzech statków wojennych należących do Ukrainy, które następnie zostały zajęte, a żołnierze wzięci do niewoli. Ten niczym nie sprowokowany incydent można określić jako kolejną próbę rozpoczęcia przez Rosję wojny (bez jej wypowiedzenia) z Ukrainą. W związku z kryzysem prezydent Ukrainy, Petro Poroszenko, wydał dekret wprowadzający na Ukrainie 26 listopada od godz. 14 stan wojenny na okres do 26 grudnia 2018 r. „Należy zaznaczyć, że FR od 2014 r. prowadzi (oficjalnie niewypowiedzianą) wojnę z Ukrainą. Od tego roku rosyjski parlament bezpodstawnie i jednocześnie sprzecznie z duchem Konstytucji FR

${ }^{74}$ Ibidem, s. 130.

75 Закон України Про оборону України Відомості Верховної Ради України (ВВР), 1992, № 9 , ст. 106.

76 Vide K. Eckhardt, Status prawny jednostki w świetle ustaw o stanach nadzwyczajnych, [w:] Problemy stosowania Konstytucji Polski i Ukrainy w praktyce, red. M. Granat, J. Sobczak, Lublin 2004, s. 166-200.

77 В. Теліпко, Науково-практичний коментар Конституиії Украӥни, Київ 2011, s. 326.

78 Vide wyrok TK z 16 marca 2011 r., w którym TK orzekł, że dekret z dnia 12 grudnia 1981 r. o stanie wojennym (Dz.U. z 1981 r. nr 29, poz. 154) jest niezgodny z art. 7 Konstytucji RP w związku z art. 31 ust. 1 konstytucji PRL z 22 lipca 1952 r. (Dz.U. z 1976, nr 7, poz. 36) oraz art. 15 ust. 1 Międzynarodowego Paktu Praw Obywatelskich i Politycznych z 1966 r. (Dz.U. z 1977, nr 38, poz. 167). 
nadał Prezydentowi FR Władimirowi Putinowi prawo do użycia wojska na terytorium Ukrainy, nie określając jednak ram czasowych. W okresie czterech lat wykorzystywania wojsk FR na Ukrainie parlament nawet raz nie uzyskał sprawozdania głowy państwa w tym zakresie. Faktycznie jest to niemożliwe, gdyż w rzeczywistości to nie parlament kontroluje prezydenta FR lecz głowa państwa parlament"79. Władze FR oficjalnie nie wskazują, że głównym celem w wojnie jest zniszczenie państwowości ukraińskiej, lecz pozorują ,szlachetny” cel ochrony ludności rosyjskojęzycznej, która nie jest w żadnej mierze prześladowana i władze ukraińskie nie zamierzają tego robić.

Destrukcyjne działania Cerkwii Prawosławnej Patriarchatu Moskiewskiego (na służbie imperialnych interesów państwa rosyjskiego) w latach 2012-2018 (oraz wcześniejszych $)^{80}$, które można przyrównać do działań tzw. piątej kolumny na Ukrainie, doprowadziły do kryzysu, jaki w niekontrolowany sposób mógł się rozwinąć. Równolegle trwały starania o powołanie na Ukrainie autokefalii popieranej przez tamtejsze elity polityczne skupione wokół prezydenta Poroszenki. Doprowadziły one do tego, że znaczna część Ukraińców nie chciała, aby miejscowe struktury cerkiewne zachowały związek z Moskwą. Prace nad uzyskaniem tomosu o przyznaniu autokefalii Prawosławnego Kościoła Ukrainy prowadziły do jeszcze większego zaostrzenia relacji rosyjsko-ukraińskich. Uwzględniając fakt, że konflikty o podłożu religijnym należą do najbardziej krwawych, uwzględniono nieformalnie okoliczności jako kolejną przesłankę uzasadniającą wprowadzenie stanu wojennego w celu ograniczenia konfliktu zbrojnego $^{81}$.

Zgodnie z rosyjską imperialistyczną doktryną Ukraińcy i Rosjanie są bratnimi narodami i dlatego Ukraińcom nie jest potrzebne własne i niepodległe państwo. Zakłada ona, że Ukraińcom powinno wystarczyć na wpół zależne od FR quasi-republika/państwo na wzór Białorusi i tak jak kiedyś Ukraińcy powinni pracować na rzecz ,wielkiej Rosji”. Rosyjska doktryna imperialna jest biegunowo sprzeczna z ideami i zasadami konstytucji Ukrainy, która gwarantuje niezależność Ukrainy od FR czy jakiegokolwiek innego państwa. Konstytucyjna doktryna Ukrainy wychodzi z założenia, że naród (lud) ukraiński - obywatele Ukrainy wszystkich narodowości — realizuje swoje

79 В. Кампо, Воєенний стан в Україні: конституційні акценти на тлі військово-політичної cumуaщiї, „Конституційний процес в Україні: політико-правові аспекти” 2018, nr 12, s. 61.

${ }^{80} \mathrm{O}$ roli Cerkwii w rosyjskiej polityce vide szerzej M. Szumada, Ukraina ..., s. 182-183.

${ }^{81}$ Sobór, na którym utworzono Kościół Prawosławny Ukrainy, odbył się 15 grudnia 2018 r. w soborze Mądrości Bożej (Sofijskim) w Kijowie. Ukraiński Kościół Prawosławny Patriarchatu Kijowskiego oraz Ukraiński Autokefaliczny Kościół Prawosławny dokonały przed nim samorozwiązania, natomiast kierowany przez Onufrego Ukraiński Kościół Prawosławny Patriarchatu Moskiewskiego nie przysłał na sobór oficjalnej delegacji. Jego duchowni, którzy przybyli na sobór z własnej inicjatywy, zostali przez UKPPM uznani za sprawców rozłamu i suspendowani. Patriarchat Konstantynopolitański uznał, że po soborze z 15 grudnia dalsza działalność UKPPM na terytorium Ukrainy nie jest już kanonicznie uzasadniona. Ostatecznie 5 stycznia 2019 r. ekumeniczny patriarcha Konstantynopola Bartłomiej I podpisał tomos o autokefalii Prawosławnego Kościoła Ukrainy. Odtąd Kościół ten jest 15. pełnoprawnym, samodzielnym (autokefalicznym) Kościołem prawosławnym. A przy tym trzecim — po greckim i rosyjskim — co do wielkości i znaczenia Kościołem prawosławnym na świecie. 
suwerenne prawa niezależnie od jakiejkolwiek innej władzy państwowej, oprócz władzy własnego państwa ${ }^{82}$.

Proces wprowadzenia stanu wojennego na Ukrainie można podzielić na cztery etapy:

1. Rada Bezpieczeństwa Narodowego i Obrony przygotowuje i przedkłada prezydentowi Ukrainy projekt propozycji wprowadzenia stanu wojennego na terytorium całego państwa bądź jego części.

2. Administracja prezydenta Ukrainy przygotowuje akt prawny w formie dekretu głowy państwa i zostaje on podpisany przez prezydenta.

3. Deputowani Rady Najwyższej w terminie dwóch dni na posiedzeniu plenarnym zatwierdzają dekret głowy państwa (większością co najmniej 226 głosów z 450 ogólnej liczby członków jednoizbowego parlamentu).

4. Dekret jest niezwłocznie ogłaszany i wchodzi w życie po zatwierdzeniu przez parlament.

Wspomniany wcześniej stan wojenny - wprowadzony dekretem prezydenta Ukrainy w 10 obwodach (odpowiednik polskich województw) sąsiadujących z FR oraz Naddniestrzem ${ }^{83}$ od 26 listopada do 26 grudnia 2018 r. oraz jego zatwierdzenie przez parlament - oznaczał realizację nowego scenariusza funkcjonowania konstytucji, który należy zbadać pod kątem problemów jego wprowadzenia ${ }^{84} \mathrm{i}$ następstw.

Niestety w związku ze skomplikowaną sytuacją wdarło się wiele chaosu w proces legislacyjny związany z wprowadzeniem i ogłoszeniem stanu wojennego: „28 listopada 2018 r. o godz. 15.18 agencje informacyjne poinformowały, iż w dzienniku «Głos Ukrainy» został opublikowany dekret prezydenta o wprowadzeniu stanu wojennego na Ukrainie z sygnaturą N393/2018 oraz ustawa nr N2630-VIII o zatwierdzeniu dekretu

82 В. Кампо, Воєенний..., s. 61.

${ }^{83}$ Naddniestrzańska Republika Mołdawska jest nieuznawanym państwem ze stolicą w Tyraspolu, są to tereny położone na lewym brzegu Dniestru oraz prawobrzeżne miasto Bendery. Obejmuje pas ziemi o długości około $200 \mathrm{~km}$ i średniej szerokości około 12-15 km (najmniejsza szerokość 6 km, największa $38 \mathrm{~km}$ ). Na arenie międzynarodowej Naddniestrze jest traktowane jako region autonomiczny Mołdawii, jej integralna część. Do utworzenia separatystycznego rządu Naddniestrza zarówno politycznie, jak i militarnie przyczyniły się władze rosyjskie. Naddniestrze od początku lat dziewięćdziesiątych pozostawało pod decydującym wpływem FR, a jego istnienie w pełni zależało od rosyjskiego wsparcia militarnego, gospodarczego i finansowego. Stacjonująca tu 14. armia rosyjska stała się stroną konfliktu mołdawsko-naddniestrzańskiego. Mimo podpisania stosownego traktatu w Stambule w 1999 r. Rosja dotąd nie wycofała swoich sił zbrojnych z terenów Naddniestrza, traktując je jako bazę dla swojego sprzętu wojskowego. Garnizony miały zostać zlikwidowane do 2003 r., jednak w czerwcu 2006 r. rosyjski minister obrony S. Iwanow zapowiedział, że rosyjska armia nie opuści republiki, dopóki w tym regionie „nie zapanuje spokój”, który FR systematycznie niszczy poprzez wszczynanie walk i inne destrukcyjne działania, np. sabotaż.

${ }^{84}$ Wyniki badania sondaży społecznych obywateli rosyjskich wskazują, że wprowadzenie na Ukrainie stanu wojennego jest równoznaczne z wypowiedzeniem wojny FR. Rezultaty rosyjskiej dezinformacji propagandowej na różnych płaszczyznach są zatrważające, gdyż ponad $90 \%$ ankietowanych obwinia Ukrainę w agresywnej wojennej polityce, gdy to Rosja jest agresorem. Przy czym dane wywiadowcze ukraińskiego wywiadu wskazują, że przy granicach z Ukrainą jest zmobilizowany sprzęt wojenny i wojsko, który jest gotowy do działań wojennych nie tylko na Ukrainie, lecz także na terenie sąsiednich krajów Unii Europejskiej. 
Prezydenta Ukrainy o wprowadzeniu stanu wojennego na Ukrainie. Od wydania stosownych aktów do ich oficjalnego parlamentarnego ogłoszenia ( $\mathrm{Nr} 226)$ upłynęły dwie doby" ${ }^{95}$. W art. 5 ustawy o reżimie prawnym stanu wojennego określono kolejność działań, m.in. kto składa stosowne propozycje projektów aktów prawnych, kiedy prezydent wydaje dekret, w jakich terminach ma zebrać się parlament dla jego zatwierdzenia oraz kiedy wchodzą w życie dekret i ustawa. Szczególnie istotne dla omawianego problemu są niezbędne elementy dekretu (art. 6 ustawy) oraz sama forma jego zatwierdzenia w drodze ustawy określone w art. 189 i 190 regulaminu Rady Najwyższej ${ }^{86}$ z 10 lutego 2010 r. Wspomniany regulamin określa wprost, że projekt ustawy zatwierdzający dekret prezydenta o wprowadzeniu stanu wojennego bądź stanu nadzwyczajnego lub przeprowadzenia mobilizacji przechodzi procedurę tylko jednego (pierwszego czytania) i może być przyjęty jedynie w całości (art. 189 pkt 5). Na podstawie art. 190 pkt 1 regulaminu RN istnieją trzy możliwości proceduralne jego zatwierdzenia:

1. Przyjęcie w całości projektu.

2. Przyjęcie projektu częściowe z rekomendacjami albo zaleceniami.

3. Odrzucenie projektu ustawy zatwierdzającej dekret prezydenta Ukrainy o wprowadzeniu stanu wojennego.

Kompetencje składania merytorycznych propozycji odnośnie do stanu wojennego i zarządzenia mobilizacji spoczywają zgodnie z art. 4 ustawy o Radzie Bezpieczeństwa Narodowego i Obrony Ukrainy na tym organie, a nie na parlamencie. Po spełnieniu wymogów określonych w ustawie mają zastosowanie kolejne normy zawarte w ustawach: o narodowym bezpieczeństwie Ukrainy ${ }^{87}$ z 21 czerwca 2018 r. o przygotowaniu mobilizacyjnym i mobilizacji ${ }^{88}$ z 21 października 1993 r. oraz o obronie Ukrainy ${ }^{89}$ z 6 grudnia $1991 \mathrm{r}$.

„W nocy z 25 na 26 listopada 2018 r. na posiedzeniu RBNiOU podjęto postanowienie rekomendujące prezydentowi Ukrainy wprowadzenie stanu wojennego na całym terytorium Ukrainy. Te rekomendacje znalazły odzwierciedlenie w dekrecie nr 390. Na podstawie tego postanowienia RBNiOU i dekretu, który je zatwierdzał, przygotowano inny dekret o wprowadzeniu stanu wojennego na Ukrainie z nr 391. Ten właśnie wariant, który zawiera propozycję sześćdziesięciodniowego terminu stanu wojennego na całym terytorium Ukrainy z maksymalnym pakietem ograniczeń praw i wolności, został przesłany do parlamentu" ${ }^{\prime 9}$. W dniu 26 listopada w Radzie Najwyższej odbyła się debata

85 М. Ставнійчук, Воєнний стан чи апогей правового хаосу, як складової політичної кризи?!, „Конституційний процес в Україні: політико-правові аспекти” 2018, nr 12, s. 46.

86 Закон України Про Регламент Верховної Ради України Відомості Верховної Ради України (ВВР), 2010, № 14-15, № 16-17, ст. 133.

87 Закон України Про національну безпеку України Відомості Верховної Ради (ВВР), 2018, № 31 , ст. 241 .

88 Закон України Про мобілізаційну підготовку та мобілізацію Відомості Верховної Ради України (ВВР), 1993, № 44, ст. 416.

89 Закон України Про оборону України Відомості Верховної Ради України (ВВР), 1992, № 9 , ст. 106 .

90 М. Ставнійчук, Воєнний..., s. 47-48. 
dotycząca wprowadzenia stanu wojennego. Wielu deputowanych podnosiło problem ograniczenia praw i wolności, uniemożliwienia przeprowadzenia w tym czasie wyborów zarówno prezydenckich, jak i parlamentarnych oraz skrócenia kampanii wyborczej. Były też przedstawione argumenty dotyczące mobilizacji wojsk rosyjskich wzdłuż granic z Ukrainą, prób przeprowadzenia farsy referendum przez tzw. separatystów ${ }^{91}$ na obszarach okupowanych przez FR oraz wizje wojny także o podłożu religijnym. Prezydent zdecydował się na kompromis, uznając wiele argumentów opozycji i tak powstał ,[...] poprawiony wariant dekretu Prezydenta Ukrainy o nr 393. W tekście pozostawiono normy dotyczące ograniczenia praw i wolności, nie dotyczył on tylko wyodrębnionych obszarów. Termin obowiązywania stanu wojennego został skrócony i doprecyzowany do $30 \mathrm{dni}$. Zmieniono więc pierwszy artykuł dekretu. Wszystkie inne elementy tego aktu prawnego począwszy od nazwy, do norm przejściowych i końcowych pozostały bez zmian. Następnie po raz kolejny została naruszona procedura przyjmowania ustaw w Radzie Najwyższej, gdyż deputowani nie otrzymali tekstu dekretu prezydenta i projektu stosownej ustawy. Nie przeprowadzono także należycie procedury pierwszego czytania oraz przyjęcia ustawy w całości" ${ }^{\prime 2}$. W związku z tym, że na Ukrainie występują dwa dzienniki urzędowe: „Hołos Ukrainy” i „Urjadowyj Kurier” 27 listopada nastąpiło kolejne zamieszanie, gdyż „Urjadowyj Kurier” zamieścił dekret prezydenta $\mathrm{nr} 390$ z 26 listopada 2018 r. oraz postanowienie RBNiOU ograniczające prawa na terenie całej Ukrainy przez $60 \mathrm{dni}$. Tego rodzaju działania stanowiły złamanie wielu obowiązujących norm prawnych, gdyż propozycje w tej materii przedkłada RBNiOU prezydentowi, a w konstytucji i innych ustawach (w tym także regulaminie parlamentu) nie przewidziano korekty tekstu prezydenckiego dekretu. Parlament nie może także uzupełniać takiej regulacji, co najwyżej może przy częściowym przyjęciu projektu opatrzeć go rekomendacjami albo zaleceniami. Trudno także ocenić, skąd wzięło się kolejne postanowienie RBNiOU z 26 listopada 2018 r. o wniesieniu zmian do postanowienia RBNiOU z 26 listopada 2018 r. dotyczące nadzwyczajnych działań w celu zabezpieczenia suwerenności i niezależności Ukrainy oraz wprowadzenia stanu wojennego na jej terenie, które zostało zatwierdzone dekretem prezydenta Ukrainy nr 392/2018 r., i opublikowane w dziennikach urzędowych „Urjadowyj Kurier” i „Głos Ukrainy" 28 listopada $2018 \mathrm{r}$. Wielu z tych problemów, nieścisłości i naruszeń prawa można było uniknąć, gdyż zarówno art. 107 konstytucji Ukrainy jak również art. 9 ustawy o RBNiOB stanowią, że w posiedzeniach tego organu może brać czynny udział przewodniczący Rady Najwyższej Ukrainy.

Wprowadzenie stanu wojennego jest decyzją, której powinna towarzyszyć refleksja, proporcjonalność i celowość. W odniesieniu do dekretu prezydenta Ukrainy o wprowadzeniu stanu wojennego z 26 listopada 2018 r. przesłankami jego wprowadzenia były: a) kolejny akt zbrojnej agresji ze strony FR, który zdarzył się w rejonie Cieśniny

${ }^{91}$ W rzeczywistości są to regularne siły zbrojne FR działające na Ukrainie bez znaków rozpoznawczych, pozorujące walki narodowo-wyzwoleńcze.

92 Ibidem, s. 47-48. 
Kerczeńskiej przeciwko okrętom Marynarki Wojennej Ukrainy wraz z następstwami; b) inne agresywne działania FR na Morzu Azowskim i Czarnym; c) realne zagrożenie masowego wtargnięcia na terytorium Ukrainy wojsk FR według wzorca okupacyjnego na Krymie oraz w rejonie Doniecka i Ługańska. Analiza okoliczności wprowadzenia stanu wojennego zmierza do stwierdzenia, że dekret o jego wprowadzeniu jest adekwatny i proporcjonalny do zagrożeń tworzonych przez FR dla niezależności i integralności terytorialnej Ukrainy. Jest oczywiste, że Ukraina nie może sobie pozwolić na analogiczne działanie, gdyż FR tylko czeka i szuka dostatecznej prowokacji, która uzasadniałaby masową agresję, pozorując „rzekomą obronę.”

Propaganda FR już dziś próbuje przedstawiać incydent kerczeński jako ukraińską prowokację, zapominając o swej militarnej agresji i uniemożliwieniu swobodnej żeglugi statków ukraińskich między swoimi portami. Zestrzelenie malezyjskiego samolotu pasażerskiego (lot MH17) 17 lipca 2014 r. nad terytorium Ukrainy rosyjskim pociskiem kierowanym przez 53. Rakietową Brygadę Sił Zbrojnych Federacji Rosyjskiej, utrudnianie śledztwa oraz sekcji zwłok i pochówków ofiar były tylko wstępem do dalszych działań uzasadniających wprowadzenie na Ukrainie stanu wojennego. Kolejnymi wrogimi krokami realizowanymi przez FR na Ukrainie było (i jest) użycie tzw. brygad sieciowych do dezinformacji i ataków na cyberprzestrzeń ${ }^{93}$ Ukrainy. Ośrodek masowego atakowania ukraińskich portali internetowych znajduje się w miejscowości Olgino oraz w budynkach rządowych przy ul. Sawuszkina w Petersburgu. Został stworzony w celu szerzenia dezinformacji i uniemożliwienia rzeczowej obiektywnej dyskusji oraz atakowania poglądów niepożądanych z punktu widzenia polityki rosyjskiej. Należy pamiętać, że „W cyberprzestrzeni państwa tracą monopol na wywołanie i prowadzenie wojny" ${ }^{\prime 4}$, co może mieć fatalne skutki. Cyberprzestrzeń Ukrainy obejmuje m.in. systemy, sieci i usługi informatyczne o szczególnie ważnym znaczeniu dla bezpieczeństwa państwa takie jak: system bankowy, systemy transportu kolejowego i lotniczego, łączności, infrastruktury wodociągowej, gazowej, energetycznej (w tym elektrownie atomowe). Wymusiło to na ukraińskim ustawodawcy liczne nowelizacje wielu ustaw oraz próby zdefiniowania trudnych problemów (takich jak: cyberprzestrzeń, cyberwojna, cyberprzestępstwa, cyberterroryzm $)^{95}$. Kolejnym elementem ingerencji zbrojnej na Ukrainie są prywatne firmy wojskowe, np. tzw. grupa Wagnera, złożone z byłych żołnierzy zawodowych, kryminalistów i najemników, szkolone i wyposażane przez FR, a następnie przerzucane na terytorium Ukrainy.

93 Cyberprzestrzeń to zarówno infrastruktura techniczna, relacje ludzi z tą infrastrukturą oraz interakcje między ludźmi z jej wykorzystaniem.

94 J. Rzuciło, J. Węgrzyn, Stany..., s. 146.

95 Interesującą kategoryzację konfliktów, które mogą zostać wywołane w cyberprzestrzeni i będą miały charakter zbrojny przedstawił M. Schmitt na podstawie formy tradycyjnych konfliktów, wyróżniając: międzynarodowy konflikt zbrojny między państwami; międzynarodowy konflikt zbrojny między narodowymi ruchami wyzwoleńczymi; konflikt zbrojny niemający charakteru międzynarodowego między państwem a organizacją zbrojną albo między takimi organizacjami; konflikt zbrojny niemający charakteru międzynarodowego. M. Schmitt, Classification of Cyber Conflict, „Jurnal of Conflict \& Security Law" 2012, nr 2, s. 247-249. 
Niepokojący w zaistniałej sytuacji jest marazm i brak sprzeciwu obywateli rosyjskich wobec łamania praw człowieka przez najemników na Ukrainie. Propaganda sukcesu na okupowanych terenach i tworzenie kolejnych republik w celu powołania w przyszłości tzw. Noworosiji wydaje się wręcz utopijna. Jednak los wielu żołnierzy i cywilów wziętych do niewoli lub jako zakładników leży w rękach dyplomacji. Należy zaznaczyć, że w początkowej fazie wojny hybrydowej (lata 2014-2016) Ukraina nie miała wystarczającego doświadczenia $\mathrm{w}$ walce $\mathrm{z}$ rosyjską agresją i okupacją oraz nie otrzymywała takiej pomocy międzynarodowej jak obecnie. Ponadto były prezydent Ukrainy Wiktor Janukowycz, jako recydywista dwukrotnie prawomocnie skazany za kradzież z rozbojem na 3,5 roku więzienia, został uznany winny zdrady stanu i skazany na 13 lat więzienia 23 stycznia 2019 r. przez sąd w Kijowie (wyrok zaoczny w pierwszej instancji). Podstawą do oskarżenia byłego prezydenta Ukrainy był jego apel do W. Putina w 2014 r. wzywający do wprowadzenia wojsk rosyjskich na Ukrainę. W. Janukowycz w 2014 r. zbiegł do Rosji i ukrywa się tam przed ukraińskim wymiarem sprawiedliwości do dziś. Dlatego dla przeciwdziałania rosyjskiej agresji w Donbasie władze na Ukrainie ograniczyły się do wprowadzenia tzw. operacji antyterrorystycznej (ATO), której celem było rozbicie ugrupowań zbrojnych tzw. separatystów i zlikwidowanie samozwańczych republik ludowych na terytorium Ukrainy. Operacja ta została następnie przekształcona w Operację Zjednoczonych Sił (OZS). Założeniem FR było stworzenie chaosu oraz sprowokowanie ataków na jej terytorium, co miało skutkować frontalnym atakiem na terytorium Ukrainy, zajęciem kolejnych terenów i stworzeniem tzw. republik ludowych na południowym wschodzie Ukrainy, połączonych następnie w tzw. Noworosję.

Przeciwdziałaniem tym zagrożeniom było właśnie wprowadzenie na okres $30 \mathrm{dni}$ stanu wojennego w celu utrzymania linii frontu na ukraińskim Donbasie oraz zmobilizowania społeczeństwa do działań obronnych (ochotnicy, wolontariat). Choć FR poprzez działania marionetkowych republik (Donieckiej i Ługańskiej) już wcześniej wprowadziła na zajętych terenach stan wojenny z godziną policyjną, cenzurą, torturami przeciwników politycznych oraz masowym użyciem propagandy.

Za niewłaściwy należy uznać sam tytuł dekretu „O wprowadzeniu stanu wojennego na Ukrainie”, gdyż podstawa prawna — art. 106 pkt 20 konstytucji — stanowi o wprowadzeniu stanu wojennego na Ukrainie [całej — uwaga A.S.] albo określonych jej terenach. Skoro wnioskodawca zdecydował się na jego wprowadzenie na określonych terenach, to należało to wyraźnie określić w tytule dekretu. Można przyjąć, że wprowadzenie stanu wojennego w 10 obwodach oraz na wodach wewnętrznych stanowiło zalecenia, które umożliwia art. 190 pkt 1 regulaminu Rady Najwyższej ${ }^{96}$. Dyskusja przed wprowadzeniem stanu wojennego na Ukrainie z udziałem konstytucjonalistów, działaczy społecznych, polityków i członków Centralnej Komisji Wybor-

${ }^{96}$ Niestety w związku z ogromną dysproporcją potencjałów militarnych FR (ok. 50 mld dolarów) i Ukrainy (ok. 3,3 mld dolarów) w budżetach obronnych i siedmiokrotnie większą liczbą żołnierzy Ukraina nie może symetrycznie odpowiadać na agresję. Niemniej wiele organizacji międzynarodowych i państw demokratycznych poparło wprowadzenie stanu wojennego na Ukrainie. 
czej często ograniczała się do krytyki i obaw o przyszłe wybory prezydenckie, które odbyły się 31 marca (I tura) i 21 kwietnia (II tura) 2019 r. oraz wybory do Rady Najwyższej przeprowadzone 21 lipca 2019 r. W przypadku przedłużenia stanu wojennego wraz z brakiem możliwości przeprowadzenia kampanii wyborczej oraz wyborów w rejonach okupowanych uniemożliwiłoby to realizację procesu wyborczego.

Kontrowersyjne jest także wejście w życie dekretu o wprowadzeniu stanu wojennego, gdyż określono w nim, że jest wprowadzony 26 listopada 2018 r. od godz. 14 na 30 dni, do godz. 14 dnia 26 grudnia 2018 r. Jednak dekret i zatwierdzająca go ustawa zaczęły obowiązywać nie 26 listopada od godz. 14, lecz 28 listopada 2018 r. Należy zaznaczyć, że zgodnie z art. 58 konstytucji „Ustawy i inne akty normatywne nie działają wstecz, z wyjątkiem przypadków łagodzących lub uchylających odpowiedzialność jednostki. Nie można odpowiadać za czyny, które w czasie ich popełniania nie były uznawane za sprzeczne z prawem.” Taki precedens można nazwać ,antydatowaniem", co może w przyszłości skutkować poważnymi problemami w procesie legislacyjnym (art. 94).

W odniesieniu do stanu wojennego nie ma jednolitego schematu rozwiązań ustrojowych, który miałby powszechne zastosowanie. W jednych krajach istnieje szczegółowe unormowanie konstytucyjne (np. RFN), w innych natomiast mamy do czynienia z ujęciem bardzo ogólnikowym (np. w Polsce i na Ukrainie) ${ }^{97}$.

Wykorzystanie doświadczeń związanych m.in. ze zbrodnią katyńską, gdzie odnalezienie ciał spowodowało przypisanie winy sprawcom, doprowadziło do zastosowania przewoźnych krematoriów umieszczonych na podwoziach ciężarówek przez przedstawicieli FR na okupowanych ukraińskich terytoriach. Zastosowanie tego typu rozwiązań ma na celu kremowanie ciał zabitych żołnierzy i najemników, by ukryć wielkość strat, jakie poniosły te oddziały i nie dopuścić do kolejnych demonstracji przy przewożeniu zwłok do Rosji (tzw. transporty „Gruzu 200” lub „Ładunku 200”), jak również w trakcie pogrzebów. Ponadto są one wykorzystywane do niszczenia ciał cywilów zamordowanych na okupowanych terytoriach w myśl zasady: „nie ma dowodu, nie ma zbrodni”98. Zarówno przeciwstawienie się agresji, jak i podjęcie odpowiednich środków mających w późniejszym czasie doprowadzić do przypisania winy sprawcom zbrodni wojennych i zbrodni przeciw ludzkości wymaga użycia szczególnych środków.

Wprowadzenie stanu wojennego wywołało także negatywny odzew w społeczeństwie, gdyż władze poczyniły zbyt mało starań do należytego przekazania przesłanek jego wprowadzenia. Sondaże badania opinii publicznej wykazały, że niemal połowa ankietowanych uważa, że został on wprowadzony w celu wydłużenia kadencji urzędującego prezydenta. Taki wynik to w większości udział rosyjskiej propagandy oraz działania opozycji parlamentarnej i pozaparlamentarnej.

97 Vide szerzej J. Jaskiernia, Akty normatywne w stanach nadzwyczajnych, [w:] Konstytucyjny system źródel prawa, red. A. Szmyt, Warszawa 2005, s. 136-156; K. Eckhardt, Status..., s. 166-178.

98 Vide J. Palowski, Rosjanie wykorzystuja mobilne krematoria w Donbasie. Próba ukrycia udziatu $w$ walkach, <https://www.defence24.pl/rosjanie-wykorzystuja-mobilne-krematoria-w-donbasie-probaukrycia-udzialu-w-walkach>, dostęp 11 II 2019. 
Zgodnie z art. 6 pkt 5 ustawy o reżimie prawnym stanu wojennego, dekret prezydenta powinien zawierać zamknięty katalog praw i wolności człowieka i obywatela, które tymczasowo mają być ograniczone w czasie obowiązywania stanu wojennego wraz z zaznaczeniem okresu obowiązywania tych ograniczeń, jak również ograniczeń związanych z funkcjonowaniem osób prawnych. Omówione już i zarazem realne zagrożenia dla bytu państwowego na różnych płaszczyznach wojny hybrydowej doprowadziły do szerokiego zaznaczenia katalogu praw oraz wolności człowieka i obywatela, które miały ulec ograniczeniom. Dekret 393/2018 przewidywał ograniczenia: w zakresie nienaruszalności mieszkania (art. 30), tajemnicy korespondencji, rozmów telefonicznych (art. 31), ingerencji w życie osobiste i rodzinne oraz ochronę danych osobowych (art. 32), prawa do swobodnego przemieszczania się, wyboru miejsca zamieszkania oraz opuszczenia terytorium Ukrainy (art. 33), prawa do swobodnego wyrażania poglądów i przekonań oraz zgromadzeń (art. 44), prawa do udziału w zarządzaniu sprawami państwa, uczestniczenia w ogólnoukraińskich i lokalnych referendach, równego dostępu do służby państwowej i samorządu lokalnego (art. 38), prawa do udziału w zgromadzeniach pokojowych (bez broni), zebraniach, wiecach, pochodach, demonstracjach (art. 39), prawa rozporządzania własnością państwową i prywatną oraz konfiskaty mienia (art. 41), prowadzenia działalności gospodarczej (art. 42), prawa pracy (art. 43), prawa do strajku (art. 44) oraz prawa do nauki (art. 53). Punkt trzeci dekretu ograniczał także prawa osób prawnych w czasie jego obowiązywania oraz odsyłał do szerokiego katalogu ograniczeń i środków przymusu realizowanych w imieniu państwa, który został zamieszczony w art. 8 ustawy o reżimie prawnym stanu wojennego ${ }^{99}$.

Realizacja założeń stanu wojennego zmieniła nieco funkcjonowanie państwa w 10 obwodach. Na terenie jego obowiązywania przeprowadzane były zajęcia dotyczące zachowań podczas napaści zbrojnej. Przeprowadzano ćwiczenia sił samoobrony terytorialnej z wojskiem i innymi służbami mundurowymi, samorządem terytorialnym, przedsiębiorcami prywatnymi oraz znacząco doposażono wojsko. Mimo ograniczenia praw i wolności organy samorządu terytorialnego pracowały normalnie. O fakcie wprowadzenia stanu wojennego zgodnie z pkt 7 dekretu został powiadomiony sekretarz generalny ONZ oraz przedstawicielstwa dyplomatyczne akredytowane na Ukrainie w związku z zawieszeniem obowiązywania niektórych praw i wolności wynikających z Międzynarodowego Paktu Praw Obywatelskich i Politycznych. Wprowadzenie stanu wojennego na Ukrainie wymusiło także na Radzie Najwyższej rozpoczęcie prac nad nowymi projektami ustaw dotyczących bezpieczeństwa obywateli ${ }^{100}$.

99 Confer art. 4 Międzynarodowego Paktu Praw Politycznych i Obywatelskich, Dz.U. z 1977 r. nr 38, poz. 168 oraz art. 15 europejskiej Konwencji o ochronie praw człowieka i podstawowych wolności, Dz.U. z 1993 r. nr 61, poz. 284.

${ }^{100}$ Między innymi projektu ustawy o obronie Ukraińców — ofiar rosyjskiego systemu karnego, gdyż wielu Ukraińców zostało wywiezionych w głąb Rosji i skazanych za przestępstwa, których nie popełnili: m.in. reżyser Ołeh Sencow, Ołeksandr Kolczenko, Stanisław Kłych oraz liczni żołnierze ukraińscy, którzy dostali się do niewoli. Ponadto ustawodawca ukraiński rozpoczął prace nad programem ochrony i rehabilitacji Ukraińców — ofiar rosyjskiego systemu karnego na okres do 2025 r. 


\section{WNIOSKI}

Stan nadzwyczajny (stan wojenny) wiąże się z koniecznością poświęcenia dóbr jednostki dla ratowania określonych wyższych wartości, w przypadku Ukrainy jest to niepodległość, integralność terytorialna oraz wybór kierunku rozwoju cywilizacyjnego i systemu sprawowania władzy (demokratycznego w wariancie zachodnim albo autorytarnego według wzorca rosyjskiego). Dekret o wprowadzeniu stanu wojennego to decyzja kontrowersyjna i wywołująca burzliwe dyskusje części społeczeństwa ukraińskiego. Do czasu wejścia w życie dekretu prezydenta Poroszenki o wprowadzeniu stanu wojennego w nauce prawa konstytucyjnego na Ukrainie panowało schematyczne spojrzenie na tę instytucję, co można uzasadnić brakiem społecznej praktyki $\mathrm{w}$ tej materii oraz przekonaniem, że instytucja ta nie będzie zastosowana w związku z podpisaniem tzw. memorandum budapesztańskiego ${ }^{101}$. Niemniej w zaistniałej sytuacji, gdy Ukraina musiała skorzystać z instytucji stanu wojennego, należałoby po przeprowadzeniu wyborów prezydenckich w 2019 r. i przyśpieszonych wyborów parlamentarnych (co już się odbyło) ponownie wprowadzić stan wojenny w celu przeciwdziałania wpływom rosyjskim na Ukrainie w postaci sabotażu i innych elementów tzw. wojny hybrydowej aż do czasu wyzwolenia ukraińskiego Krymu i Donbasu. Niestety dopóki władza na Kremlu składa się z byłych przedstawicieli Komitetu Bezpieczeństwa Państwowego (KGB), funkcjonariuszy Federalnej Służby Bezpieczeństwa (FSB) i innych przedstawicieli komunistycznego aparatu terroru, władza ta nigdy nie zaakceptuje prawa ukraińskiego narodu do niepodległości, niezależności oraz drogi do struktur euroatlantyckich. Odpowiedzią na wybrany kurs (w propagandzie rosyjskiej określany mianem tzw. obrazy) są i będą różne formy odwetu za sankcje ekonomiczne, przeciwdziałanie budowaniu gazociągu Nord Stream 2 oraz niechęć do wyboru federacyjnej i autorytarnej koncepcji państwa według wzorca rosyjskiego.

Nowelizacja konstytucji Ukrainy z 7 lutego 2019 r. ${ }^{102}$ wprowadzająca do preambuły strategiczne cele państwa w postaci pełnego członkostwa Ukrainy w Organizacji Traktatu Północnoatlantyckiego (NATO) oraz Unii Europejskiej, określająca kompetencje Rady Najwyższej w zakresie przeprowadzenia tego procesu (art. 85 pkt 5) oraz prezydenta jako gwaranta zachodniego kursu państwa (art. 102) i Gabinetu Ministrów Ukrainy

1015 grudnia 1994 r. podpisano w Budapeszcie memorandum o gwarancjach bezpieczeństwa (porozumienie międzynarodowe niemające statusu traktatu) przez prezydentów USA, Rosji i Ukrainy oraz premiera Wielkiej Brytanii, na mocy którego USA, Rosja i Wielka Brytania zobowiązały się do respektowania suwerenności i integralności terytorialnej Ukrainy oraz powstrzymania się od wszelkich gróźb użycia siły przeciwko jej niepodległości i integralności terytorialnej, a Ukraina zobowiązała się do przekazania strategicznej broni nuklearnej Rosji i przystąpienia do układu o nierozprzestrzenianiu broni jądrowej.

102 Конституція України Відомості Верховної Ради України (ВВР), 1996, № 30, ст. 141. I3 змінами, внесеними згідно із Законами № 2222-IV від 8.12.2004, BBР, 2005, № 2, ст. 44; № 2952-VI від 1.02.2011, ВВР, 2011, № 10, ст. 68; № 586-VII від 19.09.2013, ВВР, 2014; № 11, ст. 142; № 742-VII від 21.02.2014, ВВР, 2014, № 11, ст. 143 № 1401-VIII від 2.06.2016, ВВР, 2016, № 28, ст. 532; № 2680-VIII від 7.02.2019; <https://zakon.rada.gov.ua/laws/show/254\%D0\%BA/96-\%D0\%B2\%D1\%80>, dostęp 15 III 2019. 
jako zabezpieczającego realizację tego procesu (art. 116) wywołała liczne operacje rosyjskiej agentury wpływu skierowane przeciwko ustrojowi polityczno-gospodarczemu Ukrainy.

Wprowadzenie stanu wojennego powinno być poprzedzone szeroką akcją informacyjną w mediach i nauce, gdyż przeciwdziałanie rosyjskiemu reżimowi wojskowo-politycznemu, który za wszelką cenę chce wpływać na państwa sąsiednie (i nie tylko) i utrzymywać je w strefie swoich wpływów, jest niezwykle trudne. Głównym celem polityki władz Rosji jest rozczłonkowanie Ukrainy poprzez składanie formalnych i nieformalnych propozycji jej rozbioru państwom sąsiednim, dezinformację oraz pozorowanie „walk narodowowyzwoleńczych" inicjowanych przez rosyjskie służby specjalne i sponsorowanych najemników. Niestety dyplomatyczne zakończenie niewypowiedzianej wojny przez Rosję jest niemożliwe, gdyż państwo to uznaje jedynie politykę siły i siłą militarną należy jemu odpowiadać, żeby nie skończyć jako ofiara tzw. русского мира (rosyjskiego świata).

W porządku konstytucyjnym Ukrainy widoczna jest zbytnio rozbudowana biurokracja oraz nieefektywna kontrola parlamentarna w procesie zarządzania narodowym bezpieczeństwem i obroną, w szczególności siłami zbrojnymi Ukrainy oraz wyodrębnionymi siłami specjalnymi. Wynika to po części z inflacji prawa tworzonego często poza parlamentem oraz nienależytym uregulowaniu kwestii lobbingu i przejrzystości finansowania partii politycznych ${ }^{103}$. Dlatego na Ukrainie należy wzmacniać demokrację oraz inne wartości konstytucyjne i bezpieczeństwo narodowe, jak również obronę, wykorzystując w tym celu stan wojenny. Dla realizacji tych zamierzeń należy znowelizować akty normatywne dotyczące stanu wojennego i nadzwyczajnego, gdyż obecne regulacje są skonstruowane zbyt abstrakcyjnie ${ }^{104}$. Działania w tym zakresie powinny obejmować zmiany wzmacniające kontrolę parlamentarną oraz konkretyzujące ograniczenia praw człowieka przez państwo w sytuacji zagrożeń społecznych, które wpływają na żywotne interesy państwa. Racjonalnym byłoby powołanie w tym celu w Radzie Najwyższej stałej komisji ds. praw człowieka i podstawowych wolności badającej działalność organów śledczych i postępowania przedsądowe na Ukrainie.

BIBLIOGRAFIA

ŹRÓDŁA

Konstytucje

Konstytucija Ukrajinśkoji Radjanśkoji Socjalistycznoji Respubliky wid 20 kwitnja 1978 r. $<$ http://gska2.rada.gov.ua/site/const/istoriya/1978.html>.

Konstytucija Ukrajiny, pryjniata na pjati sesji Werhownoji Rady Ukrajiny 28 czerwnia 1996 r., Wyd. Konsum, Charkiw 1996.

103 Vide szerzej М. Савчин, В. Федоренко (ред.), Конституиіийна конфліктологія (конституиійні механізми подолання політичних криз), Київ 2008, s. 9-37, 107-119.

104 Vide szerzej М. Савчин, Сучасні..., s. 184-190. 
Konstytucija Ukrajiny, Czynne zakonodawstwo zi zminamy ta dopownennjamy stanom na 30 weresnia 2016 roku (oficyjnyj tekst), Wyd. Paływoda, Kyjiw 2016.

Konstytucija Ukrajiny, Widomosti Werhownoji Rady (WWR), 1996, № 30, ст. 141.

Iз змінами, внесеними згідно із Законами № 2222-IV wid 08.12.2004, WWR, 2005, № 2, st. 44 № 2952-VI wid 1.02.2011, WWR, 2011, № 10, st. 68 № 586-VII wid 19.09.2013, WWR, 2014, № 11, st. 142 № 742-VII wid 21.02.2014, WWR, 2014, № 11, st. 143 № 1401-VIII wid 2.06.2016, WWR, 2016, №28, st. 532 № 2680 VIII wid 7.02.2019<https://zakon.rada. gov.ua/laws/show/254\%D0\%BA/96-\%D0\%B2\%D1\%80>.

U s t a w y

Zakon Ukrajiny wid 26 czerwnia 1992 r. Pro nadzwyczajnyj stan, Widomosti Werhownoji Rady Ukrajiny WWR, 1992, nr 37, st. 538.

Zakon Ukrajiny wid 16 bereznia 2000 r. Pro prawowyj reżim nadzwyczajnyjnoho stanu, Widomosti Werhownoji Rady Ukrajiny WWR, 2000, nr 23, st. 176.

Zakon Ukrajiny wid 13 bereznia 2014 r. Pro Nacionalnu hwardju Ukrajiny Widomosti Werhownoji Rady Ukrajiny WWR, 2014, nr 17, st. 594.

Zakon Ukrajiny wid 22 bereznia 2001 r. Pro rozwiduwalni orhany Ukrajiny Widomosti Werhownoji Rady Ukrajiny WWR, 2001, nr 19, st. 94.

Zakon Ukrajiny wid 13 łypnia 2000 r. Pro zonu nadzwyczajnoji ekołohicznoji sytuacji Widomosti Werhownoji Rady Ukrajiny WWR, 2000, nr 42, st. 348.

Zakon Ukrajiny wid 25 czerwnia 1991 r. Pro ochoronu nawkołysznioho pryrodnoho seredowyszcza Widomosti Werhownoji Rady Ukrajiny WWR, 1991, nr 41, st. 546.

Zakon Ukrajiny wid 14 hrudnia 1999, Pro awarijno-rjatuwalni służby Widomosti Werhownoji Rady Ukrajiny WWR, 2000, nr 4, st. 25.

Kodeks cywilnoho zahystu Ukrajiny wid 2 żowtnia 2012, Widomosti Werhownoji Rady Ukrajiny WWR, 2013, nr 34-35, st. 458.

Zakon Ukrajiny wid 3 ljutoho 1993 r. Pro Cywilnu oboronu Ukrajiny, Widomosti Werhownoji Rady Ukrajiny WWR, 1993, nr 14, st. 124.

Zakon Ukrajiny wid 5 bereznja 1998 r. Pro Radu nacionalnoji bezpeky i oborony Ukrajiny, Widomosti Werhownoji Rady Ukrajiny WWR, 1998, nr 35, st. 237.

Zakon Ukrajiny wid 19 czerwnia 2003 r. Pro demokratycznyj cywilnyj kontrol nad Wojennoju orhanizacijeju i prawoochoronnymy orhanamy derżawy, Widomosti Werhownoji Rady Ukrajiny WWR, 2003, nr 46, st. 366.

Zakon Ukrajiny wid 6 hrudnia 1991 r. Pro oboronu Ukrajiny, Widomosti Werhownoji Rady Ukrajiny WWR, 1992, nr 9, st. 106.

Zakon Ukrajiny wid 10 ljutoho 2010 r. Pro Rehłament Werhownoji Rady Ukrajiny, Widomosti Werhownoji Rady Ukrajiny WWR, 2010, nr 14-15; Nr 16-17, st. 133.

Zakon Ukrajiny wid 21 czerwnia 2018 r. Pro nacionalnu bezpeku Ukrajiny, Widomosti Werhownoji Rady Ukrajiny WWR, 2018, Nr 31, st. 241.

Zakon Ukrajiny wid 21 żowtnja 1993 r. Pro mobilizacijnu pidhotowku ta mobilizacju, Widomosti Werhownoji Rady Ukrajiny WWR, 1993, nr 44, st. 416.

Inne akty normatywne i dokumenty

Międzynarodowy Pakt Praw Obywatelskich i Politycznych z 19 grudnia 1966 r., (Dz.U. z 1977 r. nr 38, poz. 167 i 168).

Europejska konwencja o ochronie praw człowieka i podstawowych wolności, Dz.U. z 1993 r. nr 61, poz. 284.

Dekłaracja pro derżawnyj suwerenitet Ukrajiny wid 16 łypnja 1990 r.

Akt prohołoszennja nezałeżnosti Ukrajiny wid 24 serpnja $1991 \mathrm{r}$. 
D e kre ty

Ukaz Prezydenta Ukrajiny wid 26 łystopada 2018 roku Nr 390/2018 Pro riszennja Rady nacjonalnoji bezpeky i oborony Ukrajiny Szczodo nadzwyczajnych zachodiw iz zabezpeczennja derżawnoho suwerenitetu i nezałeżnosti Ukrajiny ta wwedennja wojennoho stanu w Ukrajini.

Ukaz Prezydenta Ukrajiny wid 26 łystopada 2018 roku Nr 393/2018 Pro wwedennja wojennoho stanu w Ukrajini.

Orzeczenia

Wyrok Trybunału Konstytucyjnego z 16 marca 2011 r., Dz.U. z 1981 r. nr 29, poz. 154.

PIŚMIENNICTWO

Agamben G., Stan wyjątkowy, Ha!art, Kraków 2008.

Akande J., States of Emergency, [w:] The New Constitutional Law. International Association of Constitutional Law, Second World Congres, Paris/Aix-en-Provence 1987.

Banaszak B., Konstytucja Rzeczypospolitej Polskiej. Komentarz, C.H. Beck, Warszawa 2012.

Barcik J., Srogosz T., Prawo międzynarodowe publiczne, C.H. Beck, Warszawa 2007.

Brzeziński M., Stany nadzwyczajne w polskich konstytucjach, Wydawnictwo Sejmowe, Warszawa 2007.

Danieluk B., Stany nadzwyczajne, [w:] Publicznoprawne podstawy bezpieczeństwa wewnętrznego, red. M. Zdyb, Wolters Kluwer, Warszawa 2014.

Działocha K., Stany nadzwyczajne, [w:] Konstytucja Rzeczypospolitej Polskiej. Komentarz, t. IV, red. L. Garlicki, Wydawnictwo Sejmowe, Warszawa 2005.

Eckhardt K., Status prawny jednostki w świetle ustaw o stanach nadzwyczajnych, [w:] Problemy stosowania Konstytucji Polski i Ukrainy w praktyce, red. M. Granat, J. Sobczak, Verba, Lublin 2004.

Fedorenko W., Konstytucijne Prawo Ukrajiny, Lira-K, Kyjiw 2016.

Góralczyk W., Sawicki S., Prawo międzynarodowe publiczne $w$ zarysie, Wolters Kluwer, Warszawa 2009.

Jaczynowska M., Historia starożytnego Rzymu, Państwowe Wydawnictwo Naukowe, Warszawa 1978.

Jaskiernia J., Akty normatywne w stanach nadzwyczajnych, [w:] Konstytucyjny system źródet prawa, red. A. Szmyt, Wydawnictwo Sejmowe, Warszawa 2005.

Kampo W., Wojennyj stan w Ukrajini: konstytucijni akcenty na tli wijśkowo-politycznoji sytuacji. Konstytucijnyj proces w Ukrajini: polityko-prawowi aspekty, Nacionalna Biblioteka Ukrajiny im. W.I. Wernadśkoho, Kyjiw 2018.

Konstytucijna konfliktołohija (konstytucijni mechanizmy podołannja politycznych kryz), red. M. Sawczyn, W. Fedorenko, Int-t hromdjan, Kyjiw 2008.

Kowalski G., Przewrót konstytucyjny na Ukrainie w 2014 r. Analiza konstytucyjno-prawna, „Przegląd Sejmowy” 2018, nr 1.

Kraweć I., Nacjonalna bezpeka Ukrajiny: prawa ludyny w umowach nadzwyczajnoho stanu, Wyd. Cuł., Kyjiw 1998.

Kurzępa E., Stany nadzwyczajne w polskim porządku prawnym, Wydawnictwo Poltext, Warszawa 2017.

Kustra A., Stany nadzwyczajne, [w:] Prawo konstytucyjne, red. Z. Witkowski, Towarzystwo Naukowe Organizacji, Toruń 2013.

Loewenstein K., Verfassungslehre, Wissenschaftlicher Verlag, Tübungen 1968.

Ławniczak A., Monarchiczne i republikańskie głowy państwa w Europie, Kolonia Limited, Wrocław 2011. 
Mahda J., Hybrydna wijna: wyżyty i peremohty, Vivat, Charkiw 2015.

Marszałek P., Polskie prawo stanów szczególnych 1918-1939, Wydawnictwo Uniwersytetu Wrocławskiego, Wrocław 2004.

Maszkin N., Historia starożytnego Rzymu, Książka i Wiedza, Warszawa 1953.

Mołdowan W., Melaszczenko W., Konstytucijne prawo. Stownyk dowidnyk, Jumana, Kyjiw 1996.

Prawo rzymskie. Stownik encyklopedyczny, red. W. Wołodkiewicz, W. Rozwadowski, J. Kamiński, Wiedza Powszechna, Warszawa 1986.

Prokop K., Stany nadzwyczajne w Konstytucji Rzeczypospolitej Polskiej z dnia 2 kwietnia 1997 r., Temida 2, Białystok 2005.

Rzuciło J., Węgrzyn J., Stany nadzwyczajne w sytuacji szczególnego zagrożenia państwa w cyberprzestrzeni, „Przegląd Prawa Konstytucyjnego” 2015, nr 5, https://doi.org/10.15804/ ppk.2015.05.07.

Safjan M., Bosek L., Konstytucja RP, t. II, Komentarz do art. 87-243, C.H. Beck, Warszawa 2014.

Sawczyn M., Konstytucjonalizm i pryroda konstytucji: teoria i praktyka realizacji. Dysertacja na zdobuttja naukowoho stupennja doktora jurydycznych nauk, Użhorod 2013.

Sawczyn M., Suczasni tendencji konstytucjonalizmu u konteksti hlobalizacji ta prawowoho pluralizmu, Riku-U, Użhorod 2018.

Schmitt M., Classification of Cyber Conflict, „Jurnal of Conflict \& Security Law” 2012, nr 2, https://doi.org/10.1093/jcsl/krs018.

Smaga M., Administracja publiczna w czasie klęski żywiołowej, Wydawnictwo Uniwersytetu Jagiellońskiego, Kraków 2004.

Sowhyrja O., Szuklina N., Konstytucijne prawo Ukrajiny, prownyj kurs, Jurinkom Inter, Kyjiw 2012.

Sowhyrja O., Konstytucijno-prawowyj status Kabinetu Ministriw Ukrajiny: stan ta tendencji rozwytku, Jurinkom Inter, Kyjiw 2012.

Stawnijczuk M., Wojennyj stan czy apohej prawowoho chaosu, jak składowoji politycznoji kryzy?! Konstytucijnyj proces w Ukrajini: polityko-prawowi aspekty, nr 12, Nacionalna Biblioteka Ukrajiny im. W.I. Wernadśkoho, Kyjiw 2018.

Stec A., Konflikt na Ukrainie w świetle prawa międzynarodowego publicznego, [w:] Bezpieczeństwo państw Europy Środkowo-Wschodniej w kontekście konfliktu na Ukrainie, red. T. Pączek, Wydawnictwo Naukowe AP w Słupsku, Słupsk 2016.

Stec A., Polska i Ukraina na tle zmian w uktadzie geopolitycznym, „Studia nad Bezpieczeństwem" 2017, nr 2.

Stec A., Pozycja ustrojowa prezydenta w systemie konstytucyjnym Ukrainy, Kamenjar, Lwów 2014.

Stembrowicz J., Z problematyki stanu nadzwyczajnego w prawie konstytucyjnym, „Więź” 1988, nr $11-12$.

Szljachtun P., Konstytucijne prawo: słownyk terminiw, Łybid, Kyjiw 2005.

Szumada M., Ukraina jakiej nie znamy, Swiczadło, Lwów 2016.

Telipko W., Konstytucijne ta konstytucijno-procesualne prawo Ukrajiny, Centr Uczbowoji Literatury, Kyjiw 2009.

Telipko W., Naukowo-praktycznyj komentar Konstytuciji Ukrainy, Centr Uczbowoji Literatury, Kyjiw 2011.

Wierzbicki B., Materiaty do studiów nad prawem międzynarodowym, z. 1, Temida 2, Białystok 1993.

Witer M., Litopys Rewolucji Hidnosti, Piramida, Lviv 2017.

Wójtowicz K., Stany nadzwyczajne (analiza prawno-porównawcza z uwzględnieniem Projektu Konstytucji RP), Archiwum Sejmu, Komisja Konstytucyjna Zgromadzenia Narodowego, „Ekspertyzy” 1995/1996, nr 68. 